\title{
Prevalence and impacts of genetically engineered feedstuffs on livestock populations ${ }^{1}$
}

\author{
A. L. Van Eenennaam ${ }^{2}$ and A. E. Young \\ Department of Animal Science, University of California, Davis 95616
}

\begin{abstract}
Globally, food-producing animals consume 70 to $90 \%$ of genetically engineered (GE) crop biomass. This review briefly summarizes the scientific literature on performance and health of animals consuming feed containing GE ingredients and composition of products derived from them. It also discusses the field experience of feeding GE feed sources to commercial livestock populations and summarizes the suppliers of GE and non-GE animal feed in global trade. Numerous experimental studies have consistently revealed that the performance and health of GE-fed animals are comparable with those fed isogenic non-GE crop lines. United States animal agriculture produces over 9 billion foodproducing animals annually, and more than $95 \%$ of these animals consume feed containing GE ingredients. Data on livestock productivity and health were collated from publicly available sources from 1983, before the introduction of GE crops in 1996, and subsequently through 2011, a period with high levels of predominately GE animal feed. These field data sets, representing over 100 billion animals following the introduction of GE crops, did not reveal unfavorable or perturbed trends in livestock health and productivity. No study has revealed any
\end{abstract}

differences in the nutritional profile of animal products derived from GE-fed animals. Because DNA and protein are normal components of the diet that are digested, there are no detectable or reliably quantifiable traces of GE components in milk, meat, and eggs following consumption of GE feed. Globally, countries that are cultivating GE corn and soy are the major livestock feed exporters. Asynchronous regulatory approvals (i.e., cultivation approvals of GE varieties in exporting countries occurring before food and feed approvals in importing countries) have resulted in trade disruptions. This is likely to be increasingly problematic in the future as there are a large number of "second generation" GE crops with altered output traits for improved livestock feed in the developmental and regulatory pipelines. Additionally, advanced techniques to affect targeted genome modifications are emerging, and it is not clear whether these will be encompassed by the current GE process-based trigger for regulatory oversight. There is a pressing need for international harmonization of both regulatory frameworks for GE crops and governance of advanced breeding techniques to prevent widespread disruptions in international trade of livestock feedstuffs in the future.

Key words: genetic engineering, genetically modified organisms, livestock feed, safety

(C) 2014 American Society of Animal Science. All rights reserved.

J. Anim. Sci. 2014.92:4255-4278

doi:10.2527/jas2014-8124

\section{INTRODUCTION}

The first genetically engineered (GE) feed crops were introduced in 1996. Their subsequent adoption has been swift. In 2013, GE varieties were planted on more than $95 \%$ of sugar beet, $93 \%$ of soy, and $90 \%$ of all cotton and corn acres in the United States (USDA National

\footnotetext{
${ }^{1}$ This work was supported by funds from the W. K. Kellogg endowment and the California Agricultural Experiment Station of the University of California-Davis. The authors declare no competing financial interests.

${ }^{2}$ Corresponding author: alvaneenennaam@ucdavis.edu

Received May 28, 2014.

Accepted July 28, 2014.
}

Agricultural Statistics Service, 2013). Global livestock populations constitute the largest consumers of GE feed crops. Independent studies have shown the compositional equivalence of the current generation of GE crops (Cheng et al., 2008; Garcia-Villalba et al., 2008; Herman and Price, 2013; Hollingworth et al., 2003), and no significant differences in feed digestibility, performance, or health have been observed in livestock that consume GE feed (Flachowsky et al., 2012). Similarly, it is not possible to detect differences in nutritional profiles of animal products after consumption of GE feed (Guertler et al., 2010; Tufarelli and Laudadio, 2013).

Despite these findings, some states have considered legislation that would require mandatory GE labeling 
of meat, milk, and eggs derived from animals that have eaten GE feed (CAST, 2014). Furthermore, some food companies are actively targeted by campaigns to promote products from animals that are fed non-GE diets. Given the widespread adoption of GE crops, the segment of animal agriculture that is currently feeding nonGE diets is relatively small. Approximately $0.8 \%$ of U.S. cropland and $0.5 \%$ of U.S. pasture were certified organic in 2011 (USDA National Agricultural Statistics Service, 2012), and only a portion of organic crops are used for animal feed.

Our objective was to briefly review the literature on livestock GE feeding studies and the composition of animal products derived from animals fed a GE diet. We gave special attention to health studies of animals, including an analysis of publicly available data on the health of commercial livestock populations since the introduction of GE crops in 1996. Also, we summarized the global usage and trade of GE feedstuffs along with the estimated size of GE-sensitive markets. Finally, we discussed issues regarding pipeline and regulation of GE crops with modified output traits, asynchronous regulatory approvals, and novel breeding technologies.

\section{Livestock Feeding Studies with Genetically Engineered Feed}

A total of 165 GE crop events in 19 plant species, including those used extensively in animal feed (alfalfa, canola, corn, cotton, soybean, and sugar beet), have been approved in the United States (James, 2013). Before approval, each new GE crop goes through a comprehensive risk assessment. The risk analysis of GE organisms is governed by internationally accepted guidelines developed by the Codex Alimentarius Commission (www.codexalimentarius.org). One leading principle is the concept of substantial equivalence, which stipulates that any new GE variety should be assessed for its safety by comparing it with an equivalent, conventionally bred variety that has an established history of safe use. Over the past $20 \mathrm{yr}$, the U.S. Food and Drug Administration found all of the 148 GE transformation events that they evaluated to be substantially equivalent to their conventional counterparts, as have Japanese regulators for 189 submissions (Herman and Price, 2013). By contrast, plant varieties developed through other processes of achieving genetic changes (e.g., radiation mutagenesis) go through no formal risk assessment before being placed on the market. There have been instances where plants bred using classical techniques have been unsuitable for human consumption. For example, the poison $\alpha$-solanine, a glycoalkaloid, was unintentionally increased to unacceptable levels in certain varieties of potato through plant breeding resulting in certain cultivars being withdrawn from the U.S. and Swedish markets due to frequently exceeding the upper safe limit for total glycoalkaloid content (Petersson et al., 2013).

The difficulties associated with the safety and nutritional testing of whole foods/feed derived from GE crops, which contain thousands of bioactive substances, are well known (reviewed in Bartholomaeus et al., 2013). These include the fact that the quantity of the GE food that can be included in the diet of test animals is limited by the potential to generate nutritional imbalances and might not be high enough to detect adverse effects. Substantial differences in composition could be present without producing a recognizably meaningful difference between treatment groups fed whole foods. Many toxicologists concur that animal feeding trials of whole GE food have a low power to detect adverse effects and contribute little, if anything, to the safety assessment of whole foods (Kuiper et al., 2013). Far more sensitive analytical, bioinformatical, and specific toxicological methods exist to identify unintended effects resulting from plant breeding and provide more precise and quantifiable data for the safety evaluation of whole foods.

In 2013, the European Union (EU) Standing Committee on the Food Chain and Animal Health (Brussels, Belgium) adopted a regulation mandating a 90-d subchronic rodent feeding study (OECD, 1998) for every single GE transformation event. This is despite the fact that the European Food Safety Authority (2008; Parma, Italy) states that such testing is only warranted when driven by a specific hypothesis indicated by molecular, compositional, phenotypic, agronomic, or other analysis (e.g., metabolic pathway considerations) of the particular GE event. This mandate is seen by some as interference in the risk assessment of GE foods based on pseudoscience or political considerations (Kuiper et al., 2013). The United States and Australia/New Zealand explicitly do not require a 90 -d subchronic rodent feeding study or actively discourage their conduct due to their negligible scientific value.

Studies in which GE crops are fed to target (foodproducing) animals have focused less on GE risk assessment and more on evaluating the nutritional properties of the GE crop as well as resulting animal performance and health as compared to the results when fed an isogenic counterpart. Clear guidelines on experimental design for these types of studies have been developed (International Life Sciences Institute, 2003, 2007).

Multiple generations of food animals have been consuming 70 to $90 \%$ of harvested GE biomass (Flachowsky et al., 2012) for more than 15 yr. Several recent comprehensive reviews from various authors summarize the results of food-producing animal feeding studies with the current generation of GE crops (Deb et al., 2013; Flachowsky, 2013; Flachowsky et al., 2012; Tufarelli and Laudadio, 2013; Van Eenennaam, 2013). Studies have 
been conducted with a variety of food-producing animals including sheep, goats, pigs, chickens, quail, cattle, water buffalo, rabbits, and fish fed different GE crop varieties. The results have consistently revealed that the performance and health of GE-fed animals were comparable with those fed near-isogenic non-GE lines and commercial varieties. Many authors came to the same conclusion a decade ago (Aumaitre et al., 2002; Faust, 2002), suggesting that little contradictory data has emerged over the past $10 \mathrm{yr}$, despite the increased global prevalence of GE feed.

A number of long-term (of more than $90 \mathrm{~d}$ and up to $2 \mathrm{yr}$ in duration) feeding trials and multigenerational studies conducted by public research laboratories using various animal models including pigs, cows, quail, and fish have also been reviewed (Ricroch, 2013; Ricroch et al., 2013; Snell et al., 2012). Significant among these studies are 2 thorough multigenerational studies that examined the long-term effects of feeding a GE corn variety (MON810, expressing the insecticidal Cry1 Ab protein from Bacillus thuringiensis [Bt], one of the few GE corn varieties approved for cultivation in the EU) to food-producing animals, specifically, a German study in dairy cattle and an Irish study in pigs (Guertler et al., 2010, 2012; Steinke et al., 2010; Walsh et al., 2011, 2012 a, b, 2013; Buzoianu et al., 2012 a, b, c, d, 2013 a, b). The results from the multiple papers resulting from these 2 studies are summarized in Table 1. These studies were notable in that they included appropriate controls consuming isogenic non-GE lines of corn, and both comprehensively examined a range of phenotypes and indicators of growth and health and also used sophisticated techniques to look for the presence of recombinant DNA (rDNA) and Bt protein in the tissues and products derived from these GE-fed animals.

Results from these comprehensive studies revealed the compositional and nutritional noninferiority of GE corn to its isogenic control and an absence of long-term adverse effects from GE corn consumption. Organ pathology and function were similar between animals fed GE and nonGE corn, and there were no adverse effects of feeding GE corn on small intestinal morphology or the gut microbiota. Antibodies specific to the GE corn protein (Cry1Ab) were not detected in the blood, indicating the absence of an allergic-type immune response to the protein. Neither the $c r y 1 A b$ gene nor the Cry $1 \mathrm{Ab}$ protein was found in the blood, organs, or products of animals fed GE corn, indicating that neither the intact rDNA nor the intact recombinant protein migrated from the digestive system of the animal into other body tissues or edible animal products.

Even though these 2 comprehensive studies overwhelmingly revealed that a diet of Bt corn was not associated with long-term deleterious effects on the immune systems or animal performance, there were statistically significant differences in some of the parameters mea- sured. Although the authors concluded that these differences were not of biological relevance, significant findings in any parameter in animal feeding studies have been interpreted by some as evidence of harm (Dona and Arvanitoyannis, 2009). Others have pointedly responded that statistical differences per se are not "adverse effects" and need to be considered in terms of their biological importance (Rickard, 2009). The European Food Safety Authority clarified the difference between statistical significance and biological relevance (European Food Safety Authority, 2011). In the absence of some predefined understanding of what changes might be of biological relevance, studies risk becoming "hypothesisless fishing trips." Post hoc analysis of a large number of variables in a data set with a small sample size can lead to spurious conclusions because such studies "are fraught with differences that are not biologically significant between groups from simple variation and probability" (DeFrancesco, 2013).

The Federation of Animal Science Societies maintains an extensive bibliography of food-producing animal GE feeding studies (FASS 2014). Given the large number of $90-\mathrm{d}$ subchronic rodent and food-producing animal GE feeding studies that currently exist in the literature, it is worth questioning the value of more animal feeding studies as part of a GE risk assessment for crops that are substantially equivalent to conventional comparators (Flachowsky, 2013). The rationale for conducting long-term feeding trials and multigenerational studies need to be explicitly stated, especially given that GE proteins are digested in the gut and no intact GE protein has been found in the bloodstream. Once compositional equivalence has been established for a GE crop, animal feeding studies add little to the safety assessment (Bartholomaeus et al., 2013).

There are less than 100 long-term (>90 d) and multigenerational target animal GE feeding studies in the peerreviewed literature, which has prompted some to call for more of these types of feeding studies (DeFrancesco, 2013). Although such studies may seem intuitively appealing, they must result in novel useful data to justify the additional time, expense, and animal experimentation. Objective analyses of available data indicate that, for a wide range of substances, reproductive and developmental effects observed in long-term studies are not potentially more sensitive endpoints than those examined in 90-d rodent subchronic toxicity tests (European Food Safety Authority, 2008). There is no evidence that long-term and multigenerational feeding studies of the first generation of GE crops that have been conducted to date have uncovered adverse effects that were undetected by short-term rodent feeding studies (Snell et al., 2012). In the context of GE feed risk assessment, they argue that the decision to conduct long-term and 
Table 1. Summary results of 2 comprehensive evaluations of target animal effects of long-term feeding of genetically engineered feed (Bt-MON810 corn) to dairy cattle and pigs ${ }^{1}$. Table adapted from Ricroch et al. (2013)

\begin{tabular}{llll}
\hline \hline \multicolumn{4}{c}{ A. Dairy cattle study } \\
\hline Study Design & \multicolumn{1}{c}{ Methods } & Results & Conclusions \\
\hline 36 Simmental dairy cows $(9$ & Feed intake, milk production & There were no consistent effects of feeding GE & Compositional and nutritional \\
primiparous and 9 multiparous and composition, and body & corn or its isogenic control on milk composition equivalence of GE corn to its isogenic & Steinke et al. \\
per treatment group) were & condition over 25 mo & or body condition. All changes fell within & control. No long-term effects.
\end{tabular}

assigned to 2 feeding groups

and fed with diets based on

whole-crop silage, kernels,

and whole-crop cobs from

GE corn (Bt-MON810) or its

isogenic non-GE counterpart

as main components. The 765 -

$\mathrm{d}$ study included 2 consecutive Fate of cryl Ab DNA and

lactations. recombinant protein and samples from liver

\section{normal ranges.}

Gene expression pattern Statistical analysis of the examined gene

of markers for apoptosis, expression pattern revealed no significant

inflammation, and cell cycle difference in the gene expression profile of cows

from gastrointestinal tract fed transgenic or near-isogenic feed ration
All blood, milk, and urine samples were free of Milk of dairy cows fed GE corn for 25 recombinant DNA and protein. The crylAb gene mo should be classified not different was not detected in any fecal samples; however, from milk of cows fed non-GE corn. fragments of the Cry1 Ab protein were detected in feces from all cows fed transgenic feed.

from milk of cows fed non-GE corn.
Genetically engineered maize MON810 Guertler et al. does not have any effect on major genes (2012) involved in apoptosis, inflammation, and cell cycle in the gastrointestinal tract and in the liver of dairy cows.

Guertler et al (2010)

\begin{tabular}{|c|c|}
\hline $\begin{array}{l}\text { Large white } \times \text { landrace cross- } \\
\text { bred male } 40 \text {-d-old pigs ( } n= \\
\text { 40) were fed } 1 \text { of the following } \\
\text { treatments: } 1 \text { ) isogenic } \\
\text { corn-based diet for } 110 \mathrm{~d} \\
\text { (isogenic), } 2 \text { ) Bt corn-based } \\
\text { diet (MON810) for } 110 \mathrm{~d}(\mathrm{Bt} \text { ), } \\
\text { 3) isogenic corn-based diet } \\
\text { for } 30 \mathrm{~d} \text { followed by Bt corn- } \\
\text { based diet for } 80 \mathrm{~d} \text { (isogenic/ } \\
\mathrm{Bt} \text { ), and 4) Bt corn-based diet } \\
(\mathrm{MON} 810) \text { for } 30 \mathrm{~d} \text { followed } \\
\text { by isogenic corn-based diet for } \\
80 \mathrm{~d}(\mathrm{Bt} / \text { isogenic). }\end{array}$ & $\begin{array}{l}\text { Feed intake, growth, } \\
\text { characteristics, and body } \\
\text { composition. Heart, kidneys, } \\
\text { spleen and liver weight and } \\
\text { histological analysis. Blood } \\
\text { and urine analysis. } \\
\text { Effect on intestinal } \\
\text { microbiota }\end{array}$ \\
\hline
\end{tabular}

Large White $\times$ Landrace cross- Growth performance, bred male pigs ( 9 per treatment intestinal histology, and group) fed diet containing organ weight and function. $38.9 \% \mathrm{GE}$ or non-GE isogenic parent line corn for $31 \mathrm{~d}$.

\section{B. Pig study}

No difference in overall growth, body

composition, organ weight, histology and serum

, and urine biochemistry. A significant treatment

$x$ time interaction was observed for serum urea, creatinine, and aspartate aminotransferase.

Counts of the culturable bacteria enumerated in the feces, ileum, or cecum were not affected by GE feed. Neither did it influence the composition of the cecal microbiota, with the exception of a minor increase in the genus Holdemania.

On d 100, lymphocyte counts were higher $(P<$ 0.05 ) in pigs fed $\mathrm{Bt} /$ isogenic than pigs fed $\mathrm{Bt}$ or isogenic. Erythrocyte counts on d 100 were lower in pigs fed $\mathrm{Bt}$ or isogenic/Bt than pigs fed $\mathrm{Bt} /$ isogenic $(P<0.05)$. Neither the truncated Bt toxin nor the $c r y l A b$ gene was detected in the organs or blood of pigs fed Bt corn.

Short-term feeding of Bt MON810 corn to weaned pigs resulted in increased feed consumption, less efficient conversion of feed to gain, and a decrease in goblet cells/mum of duodenal villus. There was a tendency for an increase in kidney weight, but this was not associated with changes in histopathology or blood biochemistry.

Effects on the porcine intestinal microbiota were assessed through culture-

Fecal, cecal, and ileal counts of total anaerobes, Enterobacteriaceae, and Lactobacillus were not significantly different between pigs fed the dependent and -independent isogenic or Bt corn-based diets. Furthermore, approaches.

Immune responses and growth in weanling pigs. Determined the fate of the transgenic DNA and protein in vivo. high-throughput 16S rRNA gene sequencing revealed few differences in the compositions of the cecal microbiotas.

Interleukin-12 and interferon gamma production from mitogenic stimulated peripheral blood
Serum biochemical parameters did not Buzoianu et indicate organ dysfunction; changes were not accompanied by histological lesions. Long-term feeding of GE maize did not adversely affect growth or the selected health indicators investigated.

Feeding Bt corn to pigs in the context Buzoianu et of its influence on the porcine intestinal al. (2012d) microbiota is safe.

Perturbations in peripheral immune response were thought not to be age specific and were not indicative of Th 2 type allergenic or Th 1 type inflammatory responses. No evidence of $c r y l A b$ gene or Bt toxin translocation to organs or blood following long-term feeding.

The biological significance of these findings is currently being clarified in Walsh et al. (2012a)

long-term exposure studies in pigs.

Bacillus thuringiensis corn is well tolerated by the porcine intestinal Buzoianu et microbiota.

Walsh et al. (2012b)

No evidence of cryl $1 \mathrm{Ab}$ gene or protein

Walsh et al. of weaning pigs. The growth of pigs Cry1 Ab-specific IgG and IgA were not detected was not affected by feeding GE corn. in the plasma of GE corn-fed pigs. The detection Alterations in immune responses of the cryl $\mathrm{Ab}$ gene and protein was limited to the were detected; however, their biologic gastrointestinal digesta and was not found in the relevance is questionable.

kidneys, liver, spleen, muscle, heart, or blood. (2011)

al. (2012c)

continued 
Table 1. (cont.)

Large White $\times$ Landrace cross-bred female pigs (12)

- Fed for approximately 143 $\mathrm{d}$ throughout gestation and lactation $\mathrm{F}_{0}+1$ generation (offspring at birth). Large White $\times$ Landrace cross-bred pigs (10) - Corn dietary inclusion rate identical between treatments (isogenic parent line corn from service to weaning and GE corn from service to weaning $[\mathrm{Bt}]$ ) and ranged from $86.6 \%$ during gestation to $74.4 \%$ during lactation). Offspring (72) fed in 4 dietary treatments as follows: 1) non-GE corn-fed sow/ non-GE corn-fed offspring (non-GE/non-GE), 2) non-GE corn-fed sow/GE corn-fed offspring (non-GE/GE), 3) GE sows and their offspring fed corn-fed sow/non-GE corn-fed GE corn offspring (GE/non-GE), and 4) GE corn-fed sow/GE corn-fed offspring (GE/GE) for $115 \mathrm{~d}$.

Attempts to detect Cry1 Ab

protein in blood and feces at

various times.

and cold carcass weight.

Serum biochemistry.
Hematological and immune Cytokine production similar between treatments. No indication for inflammation or allergyBuzoianu et functions to detect possible Some differences in monocyte, granulocyte, or due to GE corn feeding. Transgenic inflammatory and allergenic lymphocyte subpopulations counts at some times, material or Cry1 Ab-specific antibodies responses at various times. but no significant patterns of changes. were not detected in sows or offspring.

Pig growth performance, No pathology observed in the organs. Offspring Feeding GE Bt corn from $12 \mathrm{~d}$ after $\mathrm{BW}$, and feed disappearance of sows fed Bt corn had improved growth weaning to slaughter had no adverse recorded at the time of each throughout their productive life compared to effect on pig growth performance, body dietary change (at weaning offspring of sows fed non-GE corn, regardless of composition, organ weights, carcass [d 0] and on d 30,70, and the corn line fed between weaning and harvest. characteristics, or intestinal morphology. 100 ) and at harvest (d 115). Some minor differences in average daily gain, Transgenerational consumption of GE At harvest, organ weight, carcass and spleen weights, dressing percentage, corn diets not detrimental to pig growth histological observations, and duodenal crypt depths for offspring from GE and health. fed or in average daily feed intake for offspring from sows fed GE and for GE-fed pigs or in liver weight for pigs in the GE/GE.
Buzoianu et al. (2013a)

At d 115 postweaning, GE/non-GE offspring had While other differences occurred,

GE/non-GE or GE/GE offspring and lower ileal offspring, were mostly encountered for total anaerobes than pigs on the other treatments. low-abundance, low-frequency bacterial Genetically engineered corn-fed offspring also taxa, and were not associated with had higher ileal total anaerobe counts than non- pathology. Therefore, their biological GE corn-fed offspring, and cecal total anaerobes relevance is questionable. This confirms were lower in non-GE/GE and GE/non-GE offspring than in those from the non-GE/nonGE treatment. The only differences observed for major bacterial phyla using $16 \mathrm{~S}$ rRNA gene sequencing were that fecal Proteobacteria were less abundant in GE corn-fed sows before farrowing and in offspring at weaning, with fecal Firmicutes more abundant in offspring.

The effects of feeding GE corn during first gestation and lactation on maternal and offspring health serum total protein, creatinine and gamma-glutamyltransferase activity, serum urea, platelet count, and mean cell $\mathrm{Hb}$ concentration
Genetically engineered corn-fed sows were heavier on $\mathrm{d} 56$ of gestation. Offspring from sows fed GE corn tended to be lighter at weaning. Sows fed GE corn tended to have decreased serum total protein and increased serum creatinine and gamma-glutamyltransferase activity on d 28 of lactation. Serum urea tended to be decreased on d 110 of gestation in GE corn-fed sows and in offspring at birth. Both platelet count and mean cell $\mathrm{Hb}$ concentration (MCHC) were decreased on d 110 of gestation in GE corn-fed sows; however, $\mathrm{MCHC}$ tended to be increased in offspring at birth. the lack of adverse effects of GE corn on the intestinal microbiota of pigs, even following transgenerational consumption.

There was a minimal effect of feeding GE corn to sows during gestation and lactation on maternal and offspring serum biochemistry and hematology at birth or BW at weaning.
Walsh et al. (2013)

\footnotetext{
${ }^{1} \mathrm{GE}=$ genetically engineered; $\mathrm{Bt}=$ Bacillus thuringiensis; $\mathrm{Hb}=$ hemoglobin.
}

multigenerational studies should be reserved for cases where some reasonable doubt remains following a $90-d$ feeding trial triggered by a potential hazard identified in the compositional analysis of the GE crop or other available nutritional or toxicological data.

\section{Field Datasets of Livestock Populations Fed with Genetically Engineered Feed}

Although a small number of controlled long-term and multigenerational feeding trials of commercialized GE crops in food-producing species are available in the peer-reviewed literature, large numbers of livestock in many countries have been consuming GE feed for over 15 yr. Hence, a very large and powerful set of GE-fed target animal data has been quietly amassing in public databases. United States agriculture feeds billions of food-producing animals each year, with annual broiler numbers alone exceeding the current size of the global human population (Table 2). During 2011, less than 5\% of U.S. animals within each of the major livestock sectors were raised for certified National Organic Program (NOP) markets that specifically prohibit the feeding of GE feed (Table 2). Given the increase in GE adoption rates between 2000 and 2013, it can be predicted that the vast majority of conventionally raised livestock in 
Table 2. Organic livestock production statistics in the United States (2011)

\begin{tabular}{lcccc}
\hline \hline Industry & $\begin{array}{c}\text { Number of organic } \\
\text { farms in the United States }\end{array}$ & $\begin{array}{c}\text { Number of animals } \\
\text { on organic farms }\end{array}$ & $\begin{array}{c}\text { Total number of livestock } \\
\text { animals in the United States }\end{array}$ & $\begin{array}{c}\text { Organic livestock numbers } \\
\text { as percent of the U.S. total }^{3}\end{array}$ \\
\hline Broilers & 153 & $28,644,354$ & $8,607,600,000$ & $0.33 \%$ \\
Layers & 413 & $6,663,278$ & $338,428,000$ & $1.97 \%$ \\
Turkeys & 70 & 504,315 & $248,500,000$ & $0.20 \%$ \\
Beef cows & 488 & 106,181 & $30,850,000$ & $0.34 \%$ \\
Dairy cows & 1,848 & 254,711 & $9,150,000$ & $2.78 \%$ \\
Hogs & 97 & 12,373 & $110,860,000$ & $0.01 \%$ \\
\hline
\end{tabular}

${ }^{1}$ USDA National Agricultural Statistics Service, 2012.

${ }^{2}$ USDA Economics, Statistics, and Market Information System, 2013.

${ }^{3}$ USDA Economic Research Service, 2013.

the United States consumed feed derived from GE crops over the past decade. Cumulatively, this amounts to over 100 billion animals consuming some level of GE feed between 2000 and 2011 (Table 3).

The duration and level of exposure to GE feed would be expected to vary depending on the animal industry. For example, in a typical U.S. broiler operation, chickens are fed for 42-49 d on diets that are composed of approximately $35 \%$ soybean meal and $65 \%$ corn grain, whereas in others species, longer-term exposure would be the norm (e.g., dairy cows over recurrent lactations). The average U.S. dairy cow has a productive life of $5 \mathrm{yr}$ with 3 conceptions, 3 gestations, and 3 lactations. A typical U.S. dairy diet contains $50 \%$ corn silage, $20 \%$ corn grain, and $10 \%$ dehulled soybean meal. Also, many cows receive large portions of their rations as ground corn grain, fuzzy cottonseed (no processing except for removal of the lint), or roasted full-fat soybeans. Other GE sources of animal feed include alfalfa hay, sugar beet pulp, corn distillers grains or other coproducts from corn processing, cottonseed meal, canola meal, and soy hulls. A beef cow on the range might consume only some GE alfalfa hay, but her progeny entering the feedlot might be expected to consume a ration containing high quantities of GE feed during their $120 \mathrm{~d}$ in the feedlot before harvest. Depending on the feeding stage and relative feed prices, feedlot rations will consist of about 80 to $85 \%$ grain (usually corn); distillers' grains and/or other sources of starch/

Table 3. Estimated cumulative number of livestock raised in the United States during the period from 2000 to 2011

\begin{tabular}{lr}
\hline \hline Industry & \multicolumn{1}{c}{ United States } \\
\hline Broilers & $94,683,600,000$ \\
Layer Hens & $3,722,708,000$ \\
Turkeys & $2,733,500,000$ \\
Beef cattle & $339,350,000$ \\
Dairy Cows & $33,550,000$ \\
Hogs & $1,219,460,000$ \\
Total & $102,732,168,000$ \\
\hline
\end{tabular}

${ }^{1}$ Numbers for broilers, hogs (barrows and gilts), and beef cattle (steers) are for slaughtered animals during calendar year. Dairy animals are number of dairy cows in a calendar year divided by 3 to account for 3 lactations per animal. energy; and 10 to $15 \%$ hay, silage, or other forage. The remaining share of the ration will include some protein source such as soybean or cottonseed meal (Mathews and Johnson, 2013), also likely to be of GE origin.

It would be reasonable to hypothesize that if animal feed derived from GE crops had deleterious effects on animals consuming GE feed, then animal performance and health attributes in these large commercial livestock populations would have been negatively impacted. To examine this hypothesis further, in October 2013, data on livestock health were collated from publicly available sources in the United States from before the introduction of GE crops in 1996 through 2000 through 2011, a decade when high levels of GE ingredients would be expected to be present in livestock feed based on the known extent of GE crop cultivation. Data were collected for the broiler, dairy, hog, and beef industries. In general, USDA data sets were from the Economics, Statistics, and Market Information System (2013). Additional data for broilers were available from the National Chicken Council (2011) and were 1) days to market, 2) feed efficiency (feed to meat gain ratio), and 3) percent mortality.

Yearly data on cattle condemnation rates were available for 1999 through 2002 from the USDA Food Safety and Inspection Service (FSIS) website (USDA Food Safety and Inspection Service, 2003) and from 2003 through 2007 based on a Freedom of Information Act request as reported (White and Moore, 2009). Data from 1994 was collected from the National Non-Fed Beef Quality Audit as reported (Boleman et al., 1998). Nonfed beef is from culled cows and bulls (i.e., animals that do not spend a significant amount of time being "fed" in a feedlot). Data were analyzed to compare trends before and after the introduction of GE feed into livestock diets. Regression analyses were performed for the period 1983 through 1994 as representative of a period with no GE feed and for the period from 2000 through 2011 as a period with high levels of GE feed based on high rates of GE crop adoption. Where data were available for both time periods, the slope of the regression lines between periods was compared using an unpaired $t$ test. 
Table 4. Livestock production statistics in the United States before and after the introduction of genetically engineered feed in 1996

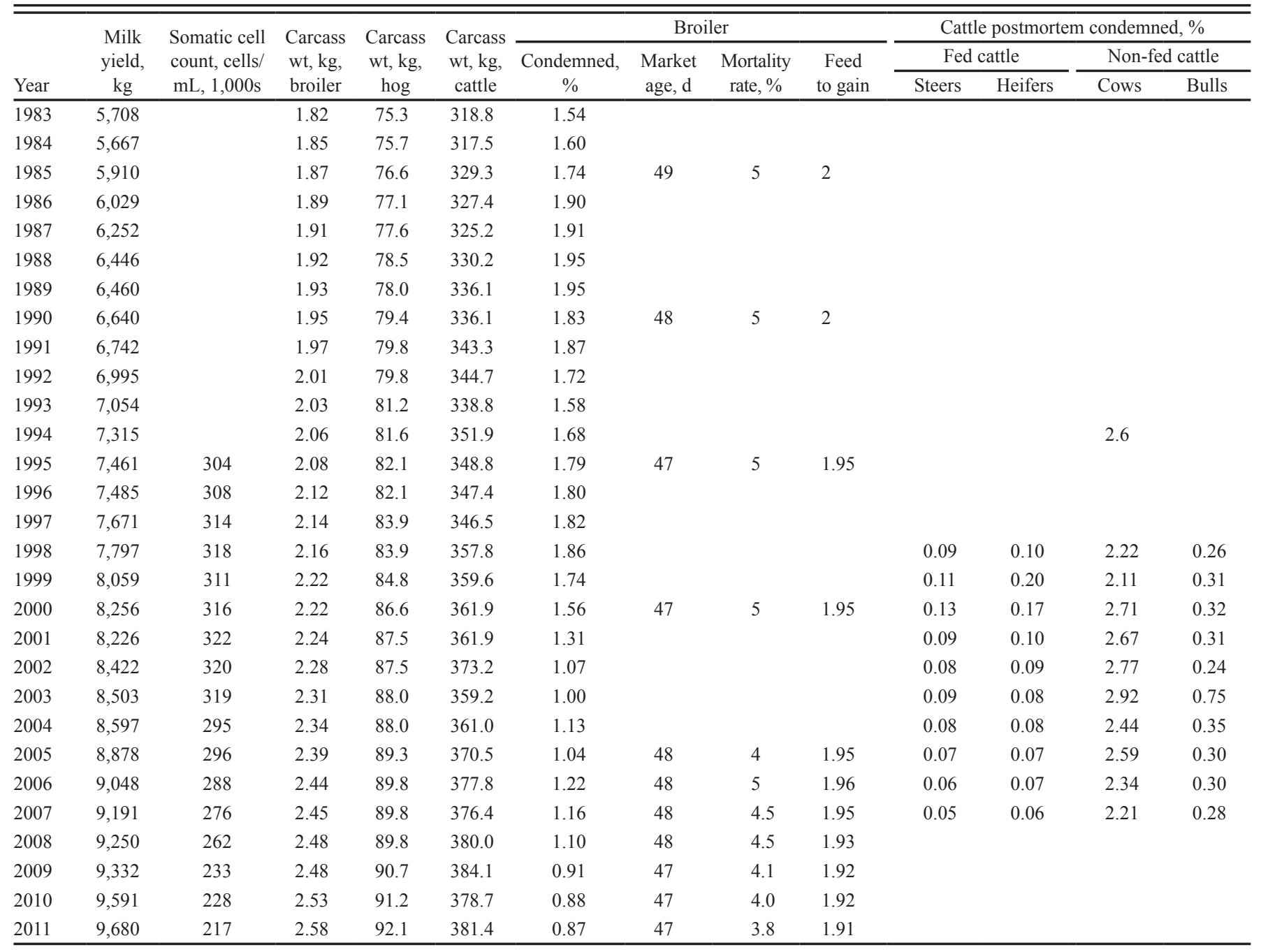

Livestock production statistics for the United States before and after the introduction of GE feed crops in 1986 are summarized in Table 4. In all industries, there were no obvious perturbations in production parameters over time. The available health parameters, somatic cell count (an indicator of mastitis and inflammation in the udder) in the dairy data set (Fig. 1), postmortem condemnation rates in cattle (Fig. 1), and postmortem condemnation rates and mortality in the poultry industry (Fig. 2) all decreased (i.e., improved) over time.

All animals arriving at USDA-inspected slaughter facilities undergo both antemortem and postmortem inspections to identify abnormalities. Carcasses are condemned postmortem if there are visible lesions or tumors present on organs and carcasses. Of the more than 163 million cattle arriving at USDA-inspected slaughter facilities for the years 2003 through 2007, a total of $769,339(0.47 \%)$ were condemned (White and Moore, 2009). Cattle fed or finished in feedyards, typically for $120 \mathrm{~d}$ before slaughter on high concentrate diets contain- ing corn and soy as major ingredients, made up the majority $(82 \%)$ of the cattle at harvest but represented a minority $(12 \%)$ of the cattle condemned. Condemnation rates for non-fed cattle, particularly cows, were higher than for fed cattle, but the rate in 2007 (2.49\%), the last year for which data are available, was similar to that reported in cattle in 1994 (2.6\%; Boleman et al., 1998), before the introduction of GE crops.

The broiler data are particularly important due to the large number of animals involved (approximately 9 billion broilers are processed annually in the United States) and the fact that there are several variables that are indicative of health (Fig. 2). The rate of broiler carcass condemnation decreased significantly over time and was at its lowest in 2011. Moreover, mortality was essentially unchanged throughout the years presented and was also at its lowest in 2011. Although broilers are exposed to large amounts of corn and soybean meal during their 42- to 49-d lifespan, they increase their body size 60fold during this period, making them very sensitive to 


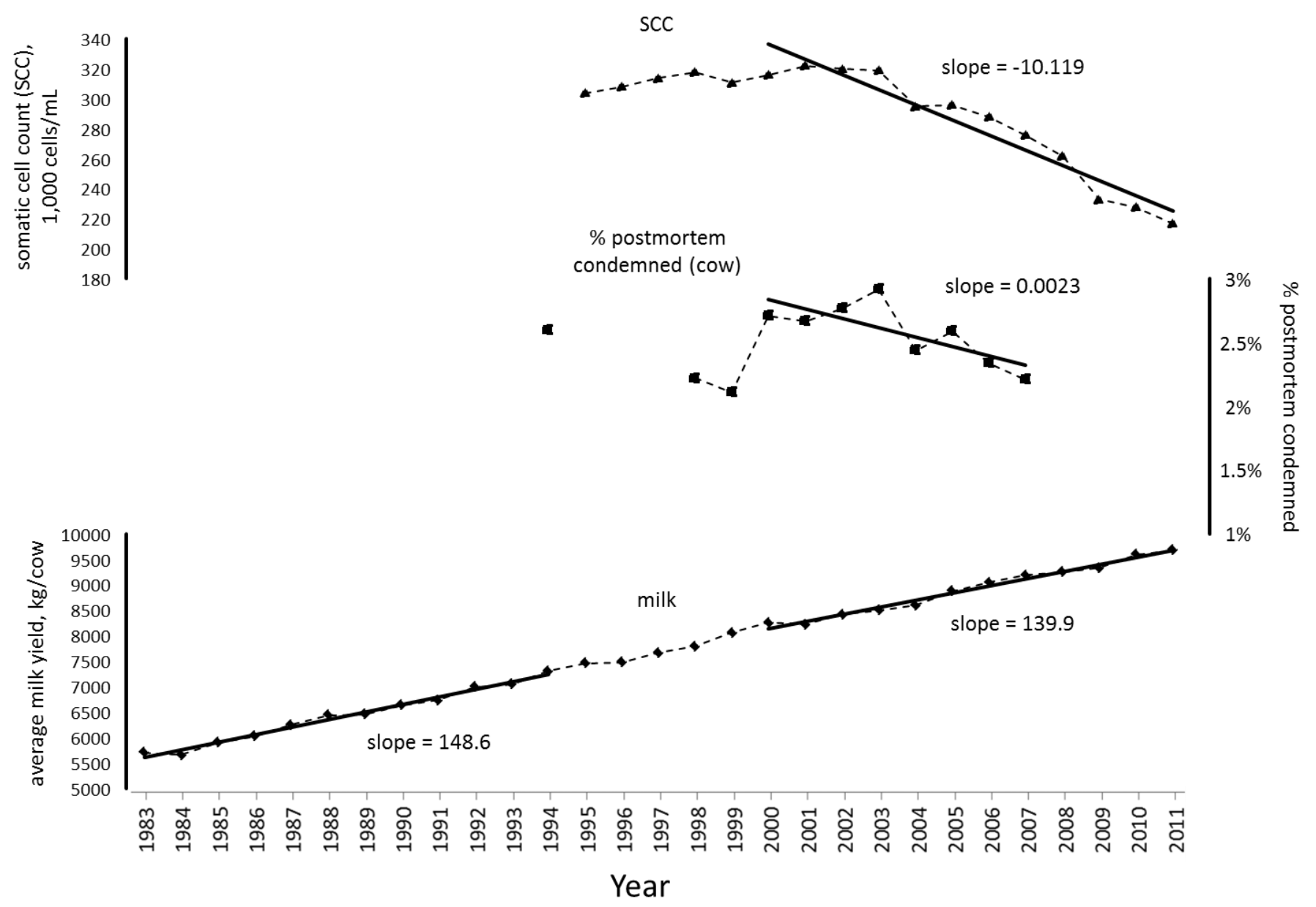

Figure 1. Milk production, percent postmortem condemned, and somatic cell counts for the United States before and after the introduction of genetically engineered crops in 1996. Sources: USDA National Agricultural Statistics Service, 2013; USDA Food Safety and Inspection Service, 2003; White and Moore, 2009; Boleman et al. (1998). Slope does not differ significantly between time periods 1983 through 1994 and 2000 through 2011.

dietary perturbations (European Food Safety Authority, 2008; International Life Sciences Institute, 2003). The conversion of feed to gain continuously decreased from 2 in 1985 to 1.91 in 2011, attributable most likely to improved genetics (Havenstein et al., 2003) and management, but this ratio is something that would be expected to worsen (i.e., increase) if the health of these animals was deteriorating following exposure to GE feed. An estimated 24 consecutive generations of broilers would have been consuming GE feed during the time period 2000 to 2011.

These field data sets representing billions of observations did not reveal unfavorable or unexpected trends in livestock health and productivity. The available health indicators from U.S. livestock suggest that these rates actually improved over time despite widespread adoption of GE crops in U.S. agriculture and increasing levels of GE content in livestock diets. There was no indication of worsening animal health after the introduction of GE feed, and productivity improvements continued in the same direction and at similar rates as those that were observed before the introduction of GE crop varieties in 1996.
A small number of experimental animal feeding studies have generated highly controversial results suggesting deleterious health effects of GE feed. Some of these reports were published and then retracted (Séralini et al., 2012), although recently and controversially republished without further peer review (Séralini et al., 2014), and others were never subjected to peer review (Ermakova, 2005; Velmirov et al., 2008). Adverse effects, including high rates of tumorogenesis, sterility, premature mortality, and histopathological abnormalities have been reported. These studies have been criticized for nonadherence to Organisation for Economic Co-operation and Development (Paris, France) consensus documents and standard protocols. Methodological flaws variously include the use of control feed that was not derived from near-isogenic lines, insufficient animal numbers to enable appropriate statistical power, lack of dose response or insufficient or no information on natural variations in test parameters, overinterpretation of differences that lie within the normal range of variation (i.e., the biological significance of differences is more important than their mere presence), and poor toxicological and/or statistical 


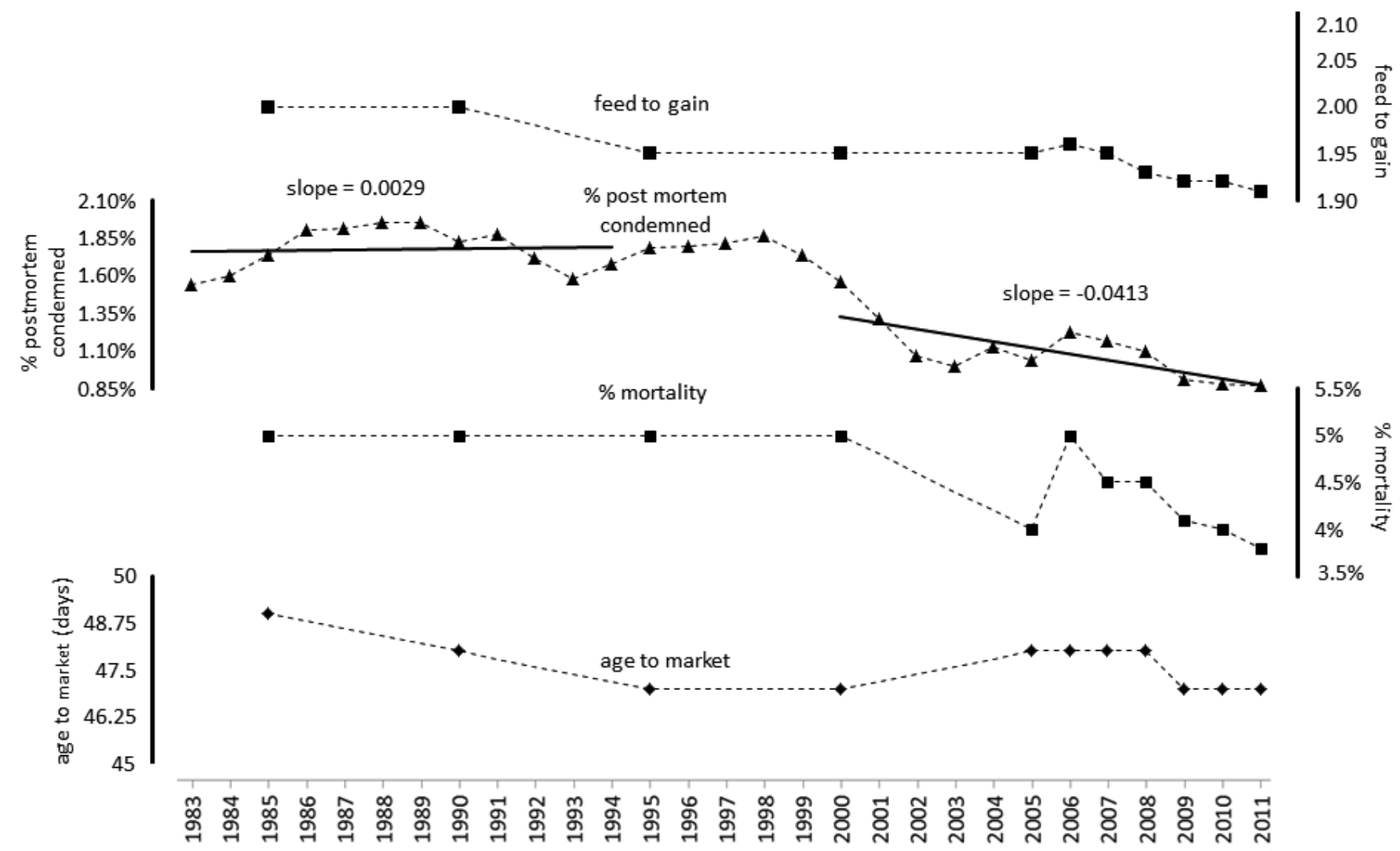

Year

Figure 2. United States broiler statistics before and after the introduction of genetically engineered crops in 1996. Sources: USDA National Agricultural Statistics Service, 2013; National Chicken Council, 2011. Slope differs between time periods 1983 through 1994 and 2000 through $2011(* P<0.05)$.

interpretation of the data (Bartholomaeus et al., 2013; European Food Safety Authority, 2012; Marshall, 2007; Schorsch, 2013; The Australian and New Zealand Food Standards Agency, 2013, 2012). A particularly succinct summary of the methodological design flaws is presented in Table 5 (Bartholomaeus et al., 2013).

Despite a wealth of studies and literature to the contrary, these isolated and poorly designed studies have resulted in the promulgation of new regulations, including a mandatory $90-\mathrm{d}$ rodent subchronic toxicity feeding study for all new GE approvals in the EU (Kuiper et al., 2013), and have generated a great deal of media attention (Arjó et al., 2013). They are also contrary to the field experience as documented by the health and production data collected on the billions of commercial food-producing animals that have primarily been consuming GE feed for over a decade. The media attention devoted to these sensational studies is exacerbating the continued controversy associated with the safety of GE food and feed and is bolstering arguments calling for the mandatory labeling of milk, meat, and eggs from GE-fed animals.

\section{Summary of Data on Recombinant DNA/protein in Milk, Meat, and Eggs from Animals Fed Genetically Engineered Feed}

Studies have concluded that animals do not digest transgenic and native plant DNA differently and that rDNA from GE crops has not been detected in animal products (Einspanier, 2013). Fragments of highly abundant plant DNA (e.g., chloroplast genomes) have been found in the digestive tracts and tissues of some species (Einspanier et al., 2001); however, neither recombinant DNA nor protein has ever been found in milk, meat, or eggs from animals that have eaten GE feed with the exception of a single study that reported the presence of fragments of transgenic DNA in both "organic" and "conventional" milk in Italy (Agodi et al., 2006). The organic milk was derived from animals not fed GE crops, so the authors postulated that the rDNA was due to feed and fecal contamination during milking of cows offered GE diets. This result has not been repeated despite recent studies using more sophisticated techniques that have looked for the presence of transgenic material in animal products (Buzoianu et al., 2012b; Deb et al., 2013; Guertler et al., 2010; Tufarelli and Laudadio, 2013). It is important to 
Table 5. Examples of limitations in experimental design, analyses, and interpretation in some whole food toxicity studies with genetically engineered (GE) crops (Bartholomaeus et al., 2013). Table reproduced with permission

\begin{tabular}{|c|c|c|}
\hline Best practices & Deficiencies observed & References \\
\hline \multicolumn{3}{|l|}{ Experimental design } \\
\hline $\begin{array}{l}\text { Identity of test and control } \\
\text { substances }\end{array}$ & $\begin{array}{l}\text { The identity of the GE test substance was not confirmed through an } \\
\text { appropriate analytical method. Confirmation of correct control and test } \\
\text { crop presence in diet was not conducted. }\end{array}$ & $\begin{array}{l}\text { Brake and Evenson (2004), Ermakova (2005), Ew } \\
\text { Pusztai (1999), Kilic and Akay (2008), and Malate } \\
\text { al. (2002a,b, 2003, 2005, 2008) }\end{array}$ \\
\hline \multirow[t]{2}{*}{ Use of appropriate control crops } & $\begin{array}{l}\text { The control crop was not of similar genetic background to the GE test } \\
\text { crop. In some studies the control was simply identified as a "wild" variety. }\end{array}$ & $\begin{array}{l}\text { Ermakova (2005), Ewen and Pusztai (1999), Mala } \\
\text { et al. (2002a,b, 2003, 2005, 2008), and Rhee et al. }\end{array}$ \\
\hline & $\begin{array}{l}\text { The test and control substances were not produced under similar } \\
\text { environmental conditions and/or no information was provided on the } \\
\text { production of test and control substances. }\end{array}$ & $\begin{array}{l}\text { Ermakova (2005), Ewen and Pusztai (1999), and } \\
\text { Malatesta et al. (2002a,b, 2003, 2005, 2008) }\end{array}$ \\
\hline $\begin{array}{l}\text { Acceptable levels of contaminants } \\
\text { (e.g., pesticides, mycotoxins, } \\
\text { other microbial toxins) in control } \\
\text { and test crops }\end{array}$ & $\begin{array}{l}\text { Study results were not interpreted in light of differences in antinutrient or } \\
\text { mycotoxin levels in test and control diets. }\end{array}$ & Carman et al. (2013) and Velmirov et al. (2008) \\
\hline $\begin{array}{l}\text { Nutritionally balanced diet } \\
\text { formulations for control and test } \\
\text { diets }\end{array}$ & $\begin{array}{l}\text { Compositional analyses were not performed on the test and control } \\
\text { substances to confirm that test and control diets had similar nutrient } \\
\text { content and were nutritionally balanced. }\end{array}$ & Ewen and Pusztai (1999) \\
\hline $\begin{array}{l}\text { Description of study design, } \\
\text { methods, and other details } \\
\text { sufficient to facilitate } \\
\text { comprehension and interpretation }\end{array}$ & $\begin{array}{l}\text { Inadequate information was provided on the source of animals used, age, } \\
\text { sex, animal husbandry practices followed, collection, and evaluation of } \\
\text { biological samples to confirm that the procedures followed met accepted } \\
\text { practices. }\end{array}$ & $\begin{array}{l}\text { Ermakova (2005), Ewen and Pusztai (1999), and } \\
\text { Séralini et al. (2012, 2014) }\end{array}$ \\
\hline
\end{tabular}

Use of appropriate statistical methods for the design of the study

Appropriate interpretation of statistical analyses

Adequate numbers of animals or test samples collected to be able to make meaningful comparisons between test and control groups Study publication and availability Publication of studies in peerreviewed journals

\begin{abstract}
Statistical methods were sometimes not provided in sufficient detail to confirm if they were conducted appropriately for the data that were collected; statistical methods were documented but were not appropriate. Estimates of statistical power were based on inappropriate analyses and magnitudes of differences.
\end{abstract}

Statistical differences were not considered in the context of the normal range for the test species, including data from historical and/or concurrent reference controls; the toxicological relevance of the difference was not considered (i.e., the reported finding is not known to be associated with adverse changes). Observed differences were not evaluated in the context of the entire data collected to determine if changes in a given parameter could be correlated with changes in related parameters.

Too few animals/group were used to make meaningful comparisons; $\quad$ Ermakova (2005), Malatesta et al. (2002a,b, 2003,

tissue sampling did not follow acceptable guidelines and was too limited 2008), and Séralini et al. (2012, 2014)

to provide an accurate assessment of what was occurring in the organ being examined. de Vendomois et al. (2009), Ewen and Pusztai (1999), Malatesta et al. $(2003,2005)$, and Séralini et al. (2007, 2012, 2014)

Carman et al. (2013), de Vendomois et al. (2009), Ewen and Pusztai (1999), Kilic and Akay (2008), Malatesta et al. (2002a,b, 2003, 2005), and Séralini et al. (2007, 2012, 2014)

Circumvention of the peer-review process removes a level of review that Ermakova (2005) and Velmirov et al. (2008) may contribute to ensuring that WF studies are appropriately designed and interpreted.

note that animals and humans regularly ingest DNA and RNA as part of traditional diets without consequence. The DNA from GE crops is chemically equivalent to DNA from other sources and both are thoroughly broken down in the gastrointestinal tract during digestion (Beever and Kemp, 2000; Jonas et al., 2001; CAST, 2006).

Intact recombinant proteins have never been detected in tissues or products of animals fed GE crops (Alexander et al., 2007). This is particularly important when considering the prospect of labeling secondary products such as milk, meat, and eggs. In some countries, mandatory food labeling regulations target the presence of GE com- ponents in the finished product (e.g., Australia, New Zealand, and Japan), whereas in other countries, regulations target foods that use GE technology as a part of the production process (e.g., the EU, Brazil, and China). It should be noted, however, that only Brazil currently requires mandatory labeling of products from animals that consume GE feed. Technically, the Brazilian law requires the label to state "(name of animal) fed with rations containing a transgenic ingredient" or "(name of ingredient) produced from an animal fed with a ration containing a transgenic ingredient.", but has yet to fully implement these laws. Given that there are no detectable and reliably 
quantifiable traces of GE materials in milk, meat, and eggs, any proposed labeling of animal products derived from GE-fed livestock would have to be based on documenting the absence of GE crops in the production chain, thereby necessitating the need for identity preservation and segregation requirements for producers and importers (Bertheau et al., 2009). This difference is important for verification: a product-based system can be enforced with testing equipment to analyze for the presence of GE materials and can filter a cheater, whereas a tracking system segregating indistinguishable products cannot guarantee the absence of products from animals that might have eaten GE feed (Gruère and Rao, 2007).

In 2012 the USDA's FSIS approved a voluntary process-based label for meat and liquid egg products that allows companies to label that they meet the Non-GMO Project's standard $(<0.9 \%$ tolerance for GE presence) for the avoidance of GE feed in the diet of the animal producing the product. The FSIS allows companies to demonstrate on their labels that they meet a third-party certifying organization's standards, provided that the claims are truthful, accurate, and not misleading. A similar approach of certifying the absence of prohibited methods in the production chain, rather than testing for some quantifiable attribute in the end product, is used for other voluntary process-based labels such as certified organic and the USDA's Agricultural Marketing Service (AMS) Process Verified Never Ever 3 (NE3) Program which requires that animals are never treated with antibiotics or growth promotants or fed animal byproducts. Again, because the products raised using these methods are indistinguishable from conventional animal products, the USDA Process Verified Program ensures that the NE3 requirements are supported by a documented quality management system.

\section{Data on Global Production and Trade in Genetically Engineered Feedstuffs and Sources of Non-Genetically Engineered Feedstuffs}

Global grain production is currently 2.5 billion $\mathrm{t}$, of which approximately $12 \%$ (300 million $\mathrm{t})$ is traded. Soy and corn make up two-thirds of global grain trade and these are the main players in commercial animal feed. Figure 3 illustrates the major global producers of these 2 crops and the proportion of global production that is from GE crop varieties. It is estimated that approximately $85 \%$ of soybean and $57 \%$ of corn grain production (USDA Foreign Agricultural Service, 2014b) are used in global livestock diets annually. The demand for livestock products has been increasing in response to population growth and income, particularly in developing countries. In Asia alone, consumption of meat and dairy products has been increasing annually by approximately 3 and 5\%, respectively (Food and Agriculture Organization of the United
Nations, 2012). Increase in demand for animal products, especially meat, will drive demand for grain and protein feeds (USDA Economic Research Service, 2008). The Food and Agriculture Organization of the United Nations (Rome, Italy) predicts that by 2050 global grain trade will double to 600 million t (Bruinsma 2009).

Of the protein sources available, soybean meal has one of the best essential AA profiles for meeting the essential AA needs of livestock and poultry. It is a good source of both lysine and methionine, which are the first limiting AA for swine and poultry, respectively. It is estimated that $79 \%$ ( 85 million ha) of global soybean hectarage is planted to GE varieties (Fig. 3). In 2013, 36.5\% of global soybean production (97.2 million $\mathrm{t}$ ) was exported and $97 \%$ came from 3 countries that grow GE soybeans - the United States, Brazil, and Argentina (Fig. 4).

Soybean meal is also an important component of animal feed globally (Fig. 5). In the 2011 to 2012 marketing year, domestic animal agriculture used 27.6 million t of U.S. soybean meal. Poultry continue to be the single largest domestic user of soybean meal, consuming about half of all meal, followed by swine. Soybean meal is a very important protein source for animal feeds in the EU, supplying $46 \%$ of the lysine supply overall. The EU imports $65 \%$ of its protein-rich feedstuffs, for which there are no alternative sources grown in the EU (Popp et al., 2013), and is the largest importer of soybean meal and the second largest importer of soybeans after China (Fig. 4 and 5). About $70 \%$ of soybean meal consumed in the EU is imported and $80 \%$ of this meal is produced from GE soybeans.

Corn is an important subsistence crop in many parts of the world and hence the majority of production is consumed within the country of production. Although only $32 \%$ (57 million ha) of global corn hectarage is planted with GE varieties (Fig. 3), 71\% of global trade came from those countries that grow GE corn varieties (Fig. 6). Approximately $11.6 \%$ (100 million $\mathrm{t}$ ) of global corn production was internationally traded in 2013. Three of the top 5 corn exporting countries - the United States, Brazil, and Argentina-currently grow GE corn. The remaining 2 countries-Ukraine and India-do not have officially registered and approved GE corn varieties.

Of the top 5 corn importing countries - Japan, Mexico, the EU, South Korea, and Egypt - only 5 countries within the EU (Spain, Portugal, Romania, Czechoslovakia, and Slovakia) grew a small amount (148,013 ha) of BtMON810 corn (USDA Foreign Agricultural Service, 2014a). Corn is the second largest category of GE products imported into the EU after soy. Unlike soybean, EU corn production is sufficient to meet most of its own corn consumption, with imports accounting for only $10 \%$ of total supply. Annual EU imports of corn products include US\$1.8 billion of corn, $\$ 151$ million of corn seed for 

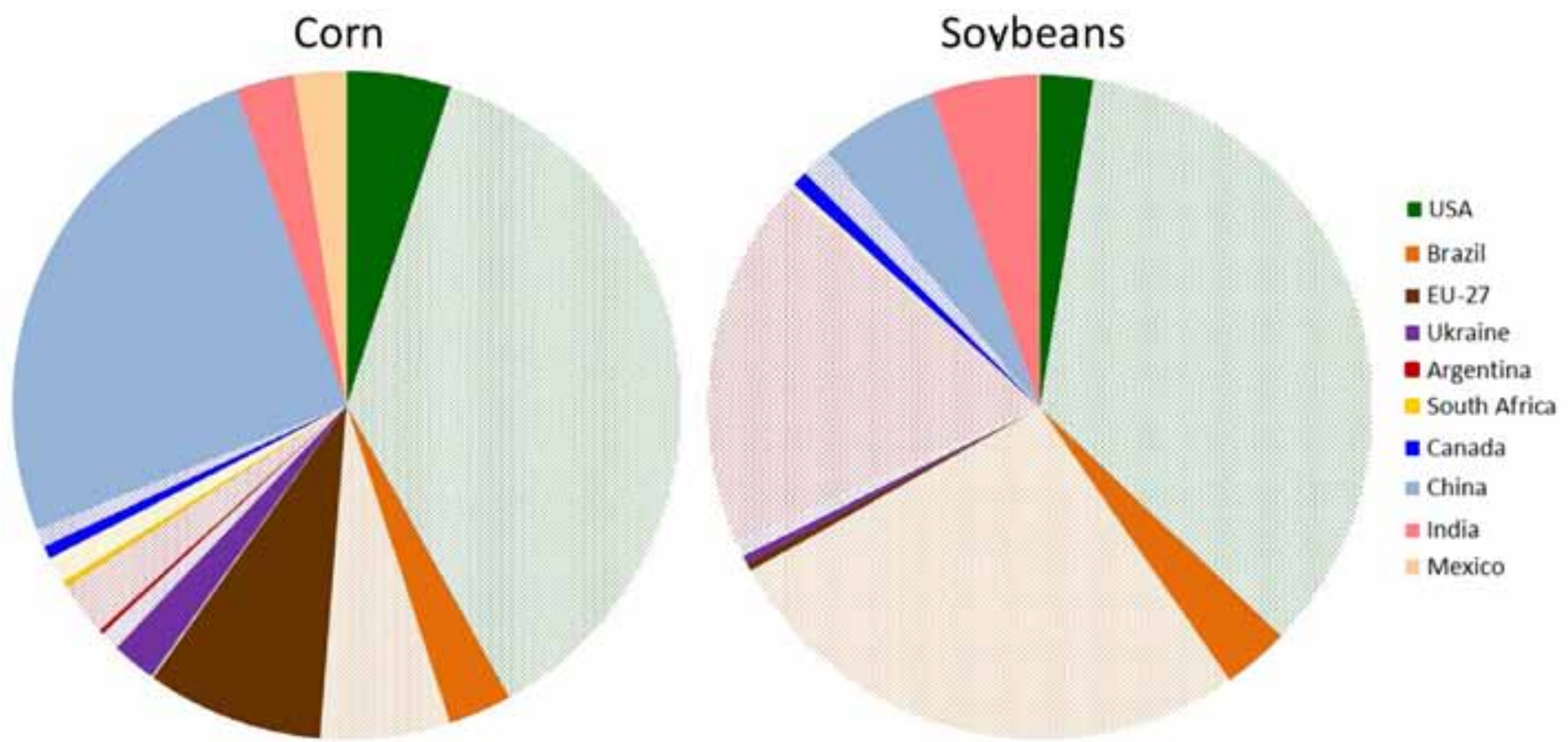

Figure 3. Genetically engineered (GE) and conventional corn and soy produced (million t) by selected countries 2012. Pattern represents production from GE varieties and solid slices represent conventional varieties. Sources: United States Department of Agriculture Foreign Agricultural Service; individual country Global Agricultural Information Network reports 2013; Food and Agriculture Organization of the United Nations (FAOSTAT). EU-27 = the 27 member states of the European Union (EU); production and trade database searches (faostat3.org/faostat-gateway/go/to/download/Q/*/E).

planting, and $\$ 87$ million of dried distillers grains (USDA Foreign Agricultural Service, 2013a).

\section{Prevalence of Markets Sourcing}

Non-Genetically Engineered Feed Globally for Livestock Populations as Compared to Conventional

World markets for grains can be separated into 4 segments: the conventional market (non-GE grain that is not certified as such), the mixed market (GE and conventional undifferentiated), the identity-preserved (certified non-GE) market, and the organic market. It is diffi-

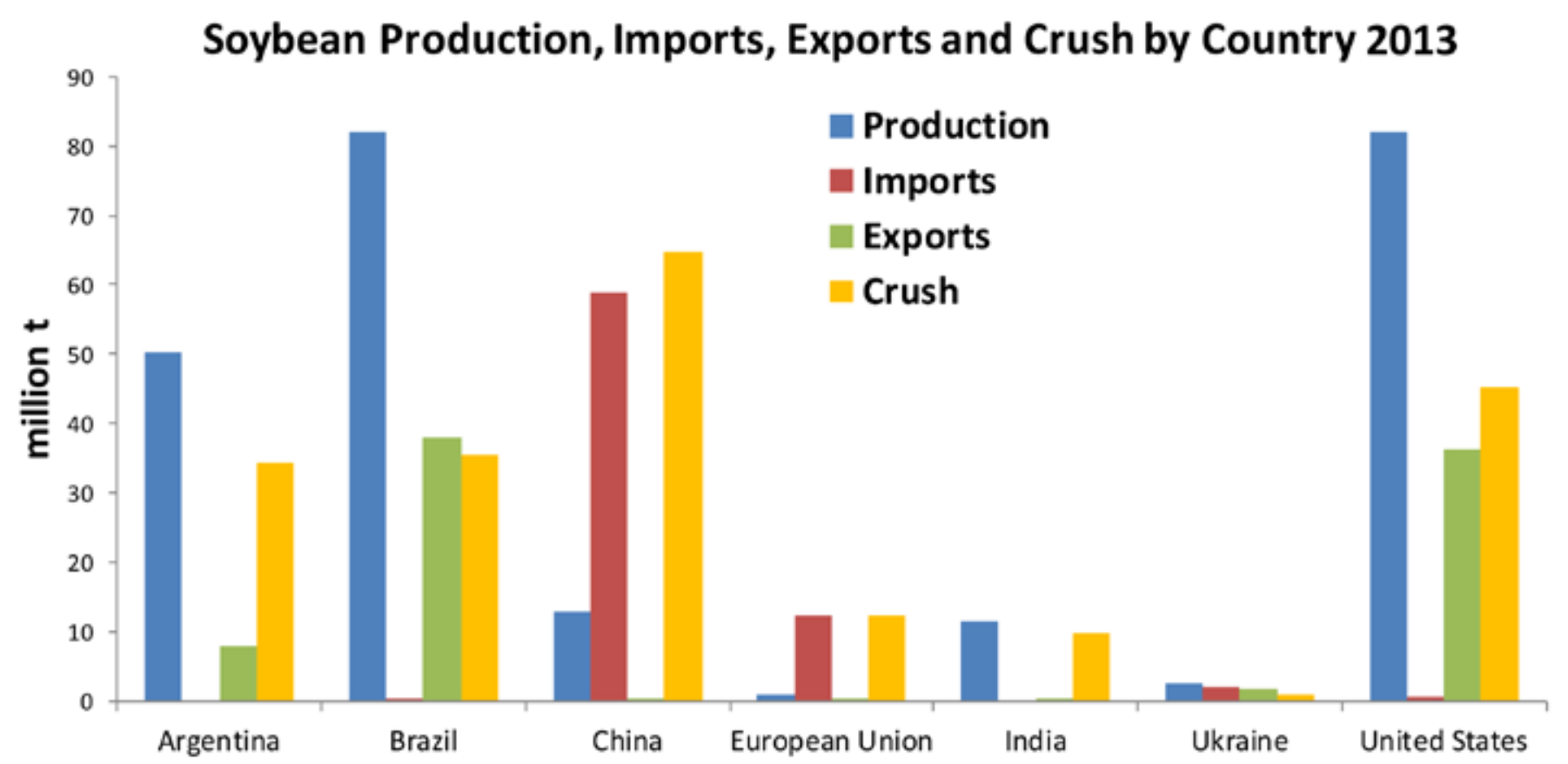

Figure 4. Soybean production, imports, exports, and crush (million t) by major import and export countries, 2013. Source: United States Department of Agriculture Foreign Agricultural Service; Production and trade database searches (http://faostat3.fao.org/faostat-gateway/go/to/download/G1/*/E). 


\section{Soybean Meal Production, Imports, Exports and Feed by Country 2013}

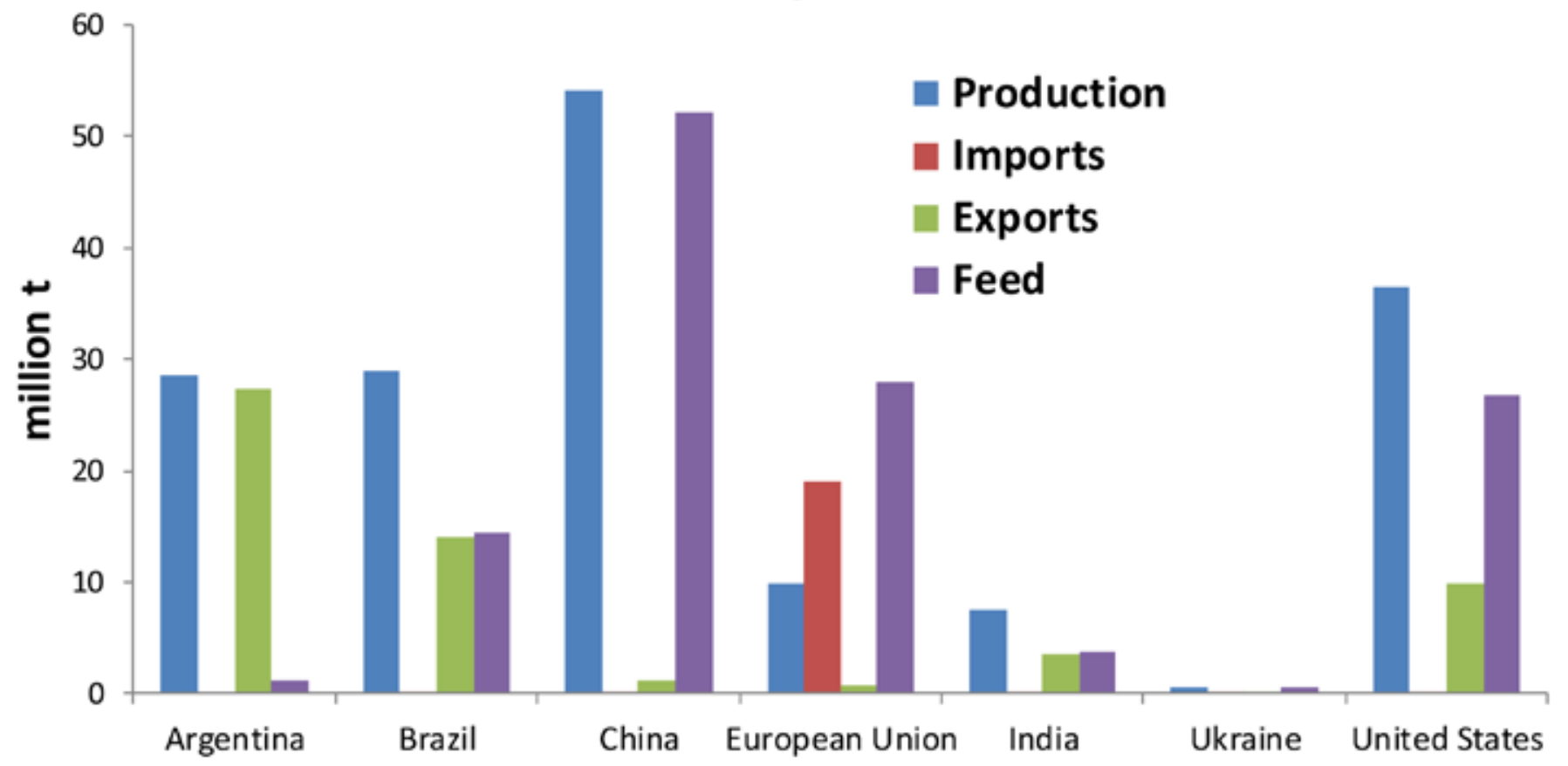

Figure 5. Soybean meal production, imports, exports, and feed (million t) by major import and export countries, 2013. Source: United States Department of Agriculture Foreign Agricultural Service; production and trade database searches (http://faostat3.fao.org/faostat-gateway/go/to/download/G1/*/E).

cult to determine exact size estimates for these different markets, although it can be stated that the conventional and mixed markets are much larger than the remaining 2.

Of the top 5 soybean meal exporting countries in 2013-Argentina, Brazil, the United States, India, and Paraguay - only India does not allow the cultivation of GE soybeans. Of the top 5 soybean meal importing countries in 2013 - the EU, Indonesia, Thailand, Vietnam, and Iran - none grow GE soybeans (USDA Foreign Agricultural Service, 2014a). It is estimated that between 4.0 and $4.5 \%$ of global trade in soybeans is required to be identity-preserved certified non-GE, and if it is assumed that this volume of traded soybeans is segregated from supplies that may contain GE soybeans, then the GE share of global trade is in the range of 93 to $96 \%$ (Table 6). A similar pattern occurs in soybean meal, where $88 \%$ of globally traded meal likely contains GE material (Table 7).

The estimated size of the export market requiring certified non-GE corn is 7.3 million t or 7\% (Table 6). This excludes countries with markets for certified nonGE corn for which all requirements are satisfied by domestic production (e.g., corn in the EU). Farm animal feed in the 27 member states of the European Union (EU-27) is composed of 50\% roughages and 10\% grains produced on farm, $10 \%$ purchased feed materials, and $30 \%$ industrial compound feed. It has been estimated that in the EU, less than $15 \%$ of the animal feed market is identity-preserved certified non-GE, although there are great variations between countries. The main driver for non-GE feed is the poultry sector $(17 \%)$ followed by the cattle $(9 \%)$ and pig sectors (2\%; European Feed Manufacturers' Federation, 2013).

The United States used to be a major supplier of corn to the EU in the 1990s but GE corn plantings in the United States caused a drastic decline in corn exports to the EU because of trade disruptions due to asynchronous approvals (i.e., cultivation approvals of specific GE varieties in the United States occurring before food and feed import approvals in the EU). The result is that the United States is no longer a major supplier of corn to the EU. Similarly, in 2007 there was a problem with asynchronous approval of a GE corn variety approved for cultivation in Argentina but unapproved for food and feed use in the EU. This concentrated demand on corn grown in Brazil, which increased prices an estimated $€ 50 /$ million $t$ for compound feed producers in the EU (Popp et al., 2013).

China, which imported an estimated 5 million $t$ of corn in 2013, making it the sixth largest corn importer, began rejecting shipments of U.S. corn in November 2013 after tests found a GE variety of corn that had been approved for cultivation in the United States, Argentina, and Brazil since 2011 but was not approved for food and feed import into China, despite a 2010 regulatory submission requesting such approval. China has a zero-tolerance policy for unapproved events. Since these trade disruptions began, a total of 3.3 million t of U.S. corn have been subject to re- 


\section{Corn by Country - Production, Imports, Export, Feed 2013}

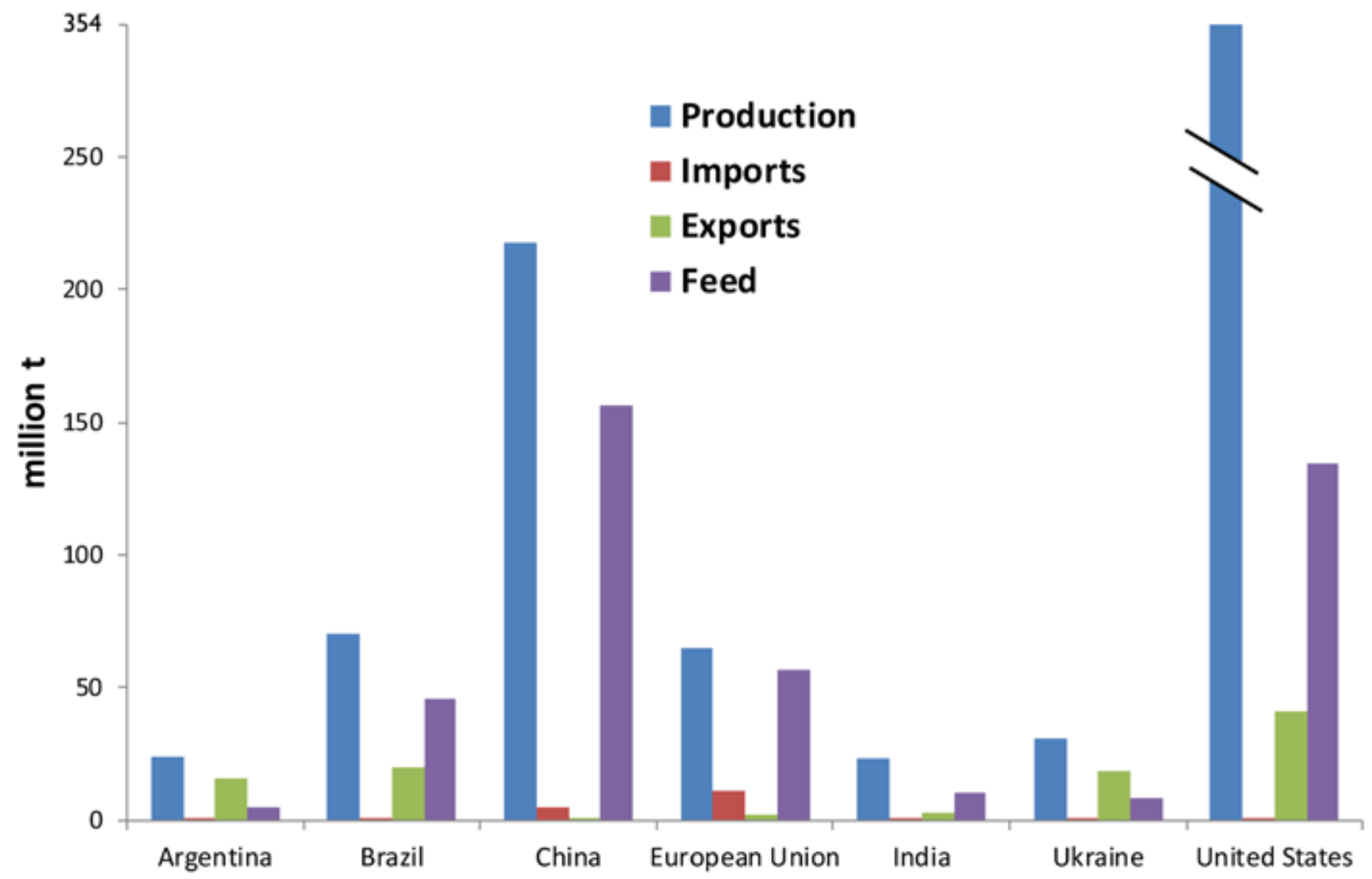

Figure 6. Corn production, imports, exports, and feed (production and trade database searches (http://faostat3.fao.org/faostat-gateway/go/to/download/G1/*/E)) by major import and export countries, 2013. Source: United States Department of Agriculture Foreign Agricultural Service; production and trade database searches(http:// faostat3.fao.org/faostat-gateway/go/to/download/G1/*/E).

jection and diverted shipments (1.4 million $\mathrm{t})$ or canceled or deferred sales. It has been estimated that up to $\$ 2.9$ billion in economic losses were sustained by the U.S. corn, distillers' grains, and soy sectors in the aftermath of the zero-tolerance enforcement policy on U.S. export shipments to China (National Grain and Feed Association, 2014).

Interestingly, Ukraine signed a 3-yr agreement with China in 2013 for the delivery of 4 to 5 million $t$ of corn per year. Ukraine does not export or import GE products as none are officially registered and approved for commercial use or sale in the country. However, private sources estimate approximately $60 \%$ of the Ukraine soybean crop and $30 \%$ of the corn crop consist of GE varieties (USDA Foreign Agricultural Service, 2013b). China only accepts GE-positive cargo if the shipment is marked accordingly and contains only those GE events that are approved for import in China as well as cultivation in the country of origin. Given asynchronous regulatory approvals and the realities of agricultural production systems where harvesting machinery and storage facilities are shared among different production systems, trade disruption appears almost unavoidable if importing countries enforce a "zero- tolerance" policy for unapproved events that have been approved for cultivation in exporting countries.

Reliance on imported animal feed is becoming increasingly complicated for countries that wish to source non-GE products due to the significant GE adoption rate worldwide. In 2013, 4 major United Kingdom food supermarket groups - Tesco, Cooperative, Marks and Spencer, and Sainsbury's - ceased requiring that poultry and egg suppliers use only non-GE feed (Popp et al., 2013). Likewise, in 2014, the German poultry industry, which feeds 0.8 million $t$ of soybean meal annually, abandoned its commitment to use only non-GE soybeans in poultry feed (USDA Foreign Agricultural Service, 2014c). This was largely due to the fact that Brazil is growing more GE soybeans and therefore has less identity-preserved certified non-GE soybeans available for export. As the global production of GE feed crops continues to rise, the EU's stringent GE tolerance levels $(0.9 \%$ GE material limit plus $0.05 \%$ measuring uncertainty tolerance) and zero tolerance for unapproved events are complicating the maintenance of non-GE supply chains (Popp et al., 2013). 
Table 6. Share of global crop trade accounted for by genetically engineered (GE) crop production 2012/2013 (million t; Brookes and Barfoot, 2014c). Table reproduced with permission

\begin{tabular}{|c|c|c|c|c|}
\hline Variable & Soybeans & Corn & Cotton & Canola \\
\hline Global production & 266 & 862.9 & 26.8 & 62.6 \\
\hline Global trade (exports) & 97.2 & 100.1 & 10.0 & 12.0 \\
\hline $\begin{array}{l}\text { Estimated size of market requiring identity-preserved (certified non-GE) market (in countries } \\
\text { that have import requirements) }{ }^{1}\end{array}$ & $4.0-4.5$ & 7.3 & Negligible & 0.1 \\
\hline Estimated share of global trade that may contain GE (i.e., not required to be segregated) & $90.1-93.2$ & 64-92.8 & 6.9 & 10.1 \\
\hline
\end{tabular}

${ }^{1}$ Estimated size of market requiring certified conventional in countries with import requirements excludes countries with markets for certified conventional for which all requirements are satisfied by domestic production (e.g., corn in the European Union [EU]). Estimated size of certified conventional market for soybeans (based primarily on demand for derivatives used mostly in the food industry): main markets: EU, 2.5 to 3.0 million t bean equivalents, and Japan and South Korea, 1 million t.

\section{Current U.S. Options for Products from Non-Genetically Engineered Fed Livestock}

Consumers wishing to purchase products from animals fed non-GE diets in the United States currently have that choice available through certified NOP products, the FSIS-approved Non-GMO Project verified label claim for meat and liquid eggs, and other non-genetically modified organism certification programs. Additionally, some private retailers are pursuing voluntary labeling. For example, in March 2013, the retail chain Whole Foods Market set a deadline that by 2018, animal products sold in its U.S. and Canadian stores must be labeled to indicate whether or not they came from animals that had consumed GE feed (Whole Foods Market, 2013). These voluntary process-based labels, in effect, verify that GE crops were not used in the production process, rather than testing for the presence of GE content in the animal products themselves as such products contain no detectable and quantifiable traces of GE materials.

Given the high rates of GE adoption in major feed crops, U.S. producers wishing to purchase non-GE feed for their livestock likely contract with growers or source identity-preserved (certified non-GE) or organic feed. In 2011, the United States had 1.26 million ha of certified organic cropland and 0.93 million ha of certified organic pasture and range (USDA National Agricultural
Statistics Service, 2012). This translates into roughly 0.8 and $0.5 \%$ of total U.S. cropland and pasture/rangeland, respectively (Fig. 7). The availability and cost of certified organic feeds is a major challenge for U.S. organic livestock producers. The costs of certified organic feedstuffs are 2 to 3 times greater than non-organicallygrown feeds (Hafla et al., 2013).

United States feed grain distributors and soy product manufacturers report sourcing organic soybeans from other countries. Organic farmers and handlers anywhere in the world are permitted to export organic products to the United States if they meet NOP standards and are certified by a USDA-accredited organic certification body. In 2007, USDA-accredited groups certified 27,000 producers and handlers worldwide to the U.S. organic standard, with approximately 16,000 in the United States and 11,000 in over 100 foreign countries (Grow and Greene, 2009). In 2007, approximately half of the accredited foreign organic farmers and handlers certified to NOP standards were in Canada, Italy, Turkey, China, and Mexico. Organic farming is often labor intensive, and developing countries with lower farm labor costs may have a competitive advantage in the production of some organic products.

In 2009, Canada was the main market for U.S. organic exports, while countries in Latin America, including Mexico, Brazil, Argentina, and Uruguay, along

Table 7. Share of global crop derivative (meal) trade accounted by genetically engineered (GE) product 2012/2013 (million t; Brookes and Barfoot, 2014c). Table reproduced with permission

\begin{tabular}{|c|c|c|c|}
\hline Variable & Soymeal & Cottonseed meal & Canola/rape meal \\
\hline Global production & 179.3 & 20.5 & 34.9 \\
\hline Global trade (exports) & 57.2 & 0.6 & 5.6 \\
\hline $\begin{array}{l}\text { Estimated size of market requiring identity-preserved (certified non-GE) market (in countries that have } \\
\text { import requirements) }{ }^{1}\end{array}$ & 2.1 & Negligible & Negligible \\
\hline Estimated share of global trade that may contain GE (i.e., not required to be segregated) & 48.3 & 0.63 & 3.6 \\
\hline
\end{tabular}

${ }^{1}$ Estimated size of certified conventional market for soymeal: European Union, 2 million t, and Japan and South Korea, 0.1 million $\mathrm{t}$ (derived largely from certified conventional beans referred to in Table 6). 

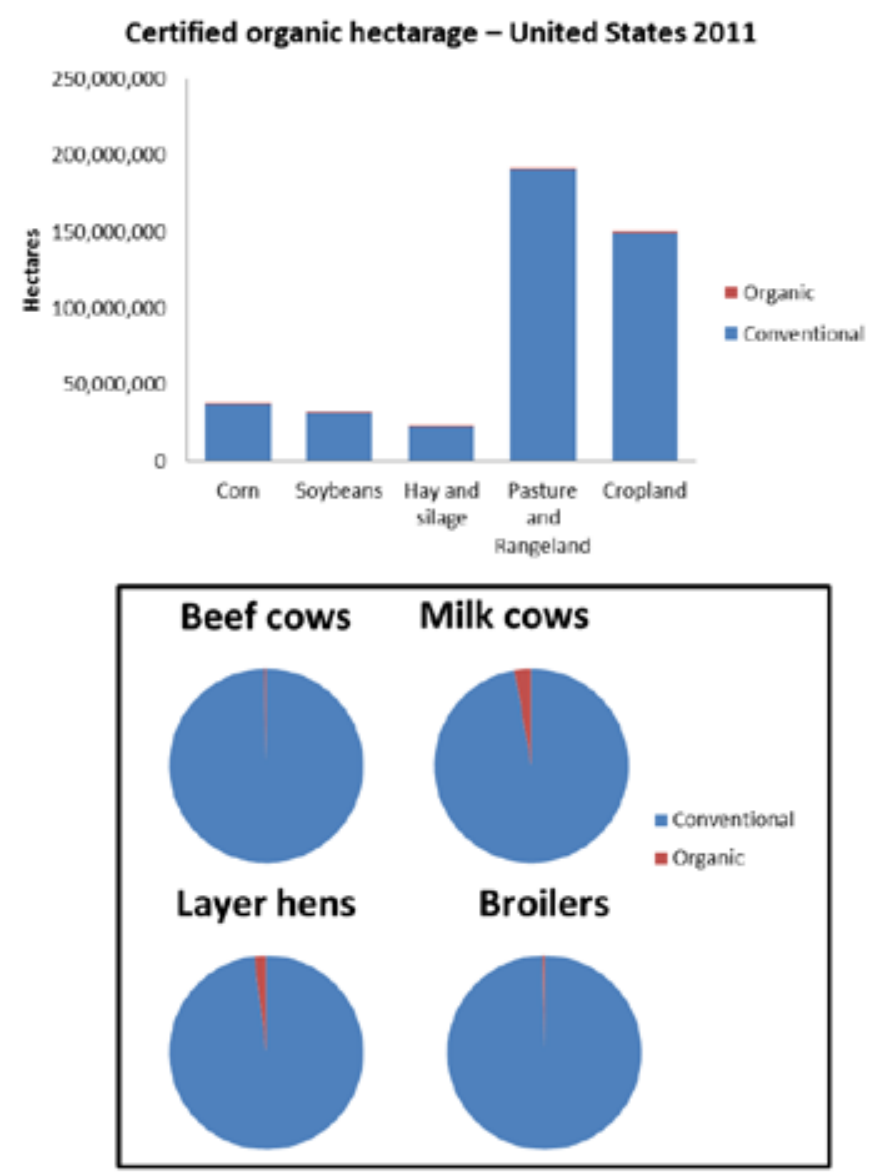

Figure 7. Certified National Organic Program hectarage and livestock numbers as a percentage of conventional U.S. numbers, 2011. Source: USDA National Agricultural Statistics Service, 2012. www.ers.usda.gov/datafiles/Organic Produc tion/National_Tables_/CertifiedandtotalUSacreageselectedcropslivestock. xls. See online version for figure in color.

with China and other countries in Asia are major sources of organic imports (Grow and Greene, 2009). The countries with the fastest growth in organic production are those that produce organic products for export including China, Bolivia, Chile, Uruguay, and Ukraine. The amount of organic farmland increased well over $1,000 \%$ in these countries between 2002 and 2006, while organic farmland in Europe and North America showed slower (27-80\%) expansion rates (Grow and Greene, 2009). In 2013, the United States imported over $\$ 100$ million of organic soybeans primarily from China and India (Fig. 8; Global Agricultural Trade System online [GATS] organic products www.fas.usda. gov/commodities/organic-products). The proportion of organic imports used for livestock feed versus human food purposes is unavailable as import product codes do not distinguish between these uses. Improved data collection is necessary to better describe international trade patterns in organic and identity-preserved (certified non-GE) feed.

\section{Dairy}

Organically raised livestock accounted for $\$ 1.31$ billion in sales in 2011, the last year with a complete set of data on production and sales. Organic milk led livestock commodities, accounting for $\$ 765$ million, or $58 \%$, of organic animal product sales; however, less than $2 \%$ of U.S. dairy production is currently organic (Hafla et al., 2013). During 2011, approximately 254,700 dairy cows (2.78\% of the total U.S. dairy herd; Table 2 ) on 1,848 dairy operations were certified organic. Production costs for organic dairies are greater than for conventional dairies due to the increased cost of organic feed and the increased use of labor and capital, which is not scale neutral as the total costs per unit of production drops sharply as herd size increases. Using pasture as a source of dairy forage is more common on organic dairies, which can help to reduce feed costs per cow but also contributes to lower production per cow. The U.S. organic dairy systems depend on the willingness of consumers to pay a premium (Hafla et al., 2013). The retail price for organic milk between 2004 and 2007 averaged 3 times the cost of conventional milk (USDA Economic Research Service, 2012b), and in 2013, organic milk made up $4.38 \%$ of total U.S. fluid milk market sales.

\section{Beef}

Natural, organic (grain-fed or otherwise), and grass/ forage-fed (including cattle finished on grasses/forages to a specific quality standard) account for about $3 \%$ of the U.S. beef market (Mathews and Johnson, 2013). The term "natural" is not associated with an official production process standard so natural beef may come from animals that have consumed GE feed. Likewise, the USDA NE3 Process Verified Program does not mandate or specify the use of non-GE feed.

Beef from grass-fed ruminants can be labeled with a "grass (forage) fed" marketing claim through the AMS Process Verified Program if fed according to USDA standards. Under this verification standard, grass or forage must be the exclusive feed source throughout the lifetime of the ruminant animal except for milk consumed before weaning. The animal cannot be fed grain or any grain byproduct before marketing and must have continuous access to pasture during the growing season. However, silage is an accepted feed that can consist of relatively large portions of grain. For example, corn silage, which averages 10 to $20 \%$ grain and can consist of up to a third or more grain, blurs the distinction between grain fed and forage fed (Mathews and Johnson, 2013).

In a survey of certified organic beef producers in the United States, $83 \%$ reported that cattle were raised exclusively or predominantly on grass and hay until 
slaughter, while the remaining $17 \%$ reported using a grain finishing system (Hafla et al., 2013). Organic beef cattle may be finished in feedlots for no more than $120 \mathrm{~d}$ and must have access to pasture during this time. In $2011,106,181$ beef cows $(0.34 \%$ of the total U.S. beef cows; Table 2) and 113,114 unclassified cows and young stock were raised in certified organic production systems. The price of natural/organic beef averaged $\$ 12.08 / \mathrm{kg}$ in the first quarter of 2011 , which represented a premium of $\$ 3.75 / \mathrm{kg}$.

\section{Poultry}

The largest volume of organic meat sales is for poultry. In 2011, the number of certified organic broilers totaled more than 28 million $(0.33 \%$ of the total U.S. broilers; Table 2), layer hens totaled more than 6.6 million (1.97\% of the total U.S. layers), and turkeys totaled 504,000 (0.20\% of the total U.S. turkeys). In 2011, sales of U.S. organic broilers and eggs totaled $\$ 115$ million and \$276 million, representing 0.5 and $3.7 \%$ of total sales, respectively. The retail price for organic poultry and eggs between 2004 and 2006 was approximately twice that of conventional products (USDA Economic Research Service, 2012a).

Currently, the size of the market for products derived from animals raised in production systems that use either identity-preserved certified non-GE or organic feed is less than 5\% (Fig. 7). Voluntary labeling programs and market premiums exist for products derived from animals that have not consumed GE feed. Mandating the labeling of products derived from animals that have eaten GE-feed at the current time would result in labeling essentially all products derived from conventionally raised livestock (i.e., $>95 \%$ of all animal products) in the United States.

If suppliers and marketers respond to mandatory labeling of products from animals fed GE feed by increasing the offering of products from animals fed non-GE feed, an increase in the non-GE feed supply would be required. This could come from non-GE feed sources (e.g., wheat and barley), from contracting with U.S. growers to plant non-GE crop varieties, or from imported feed sources. Reversion from GE to conventional crop varieties would require the adoption of altered agronomic practices to manage those crops and relinquishment of the documented environmental and economic benefits associated with the adoption of GE crops (Areal et al., 2013; Fernandez-Cornejo et al., 2014; Green, 2012; NRC, 2010). The prices received by U.S. non-GE corn and soybean producers in recent years have averaged $15 \%$ more than the prices received by conventional commodity producers (CAST, 2014), and globally traded non-GE soybean meal is roughly at a $13 \%$ premium to conventional soybean meal prices. Given the importance of feed costs in overall

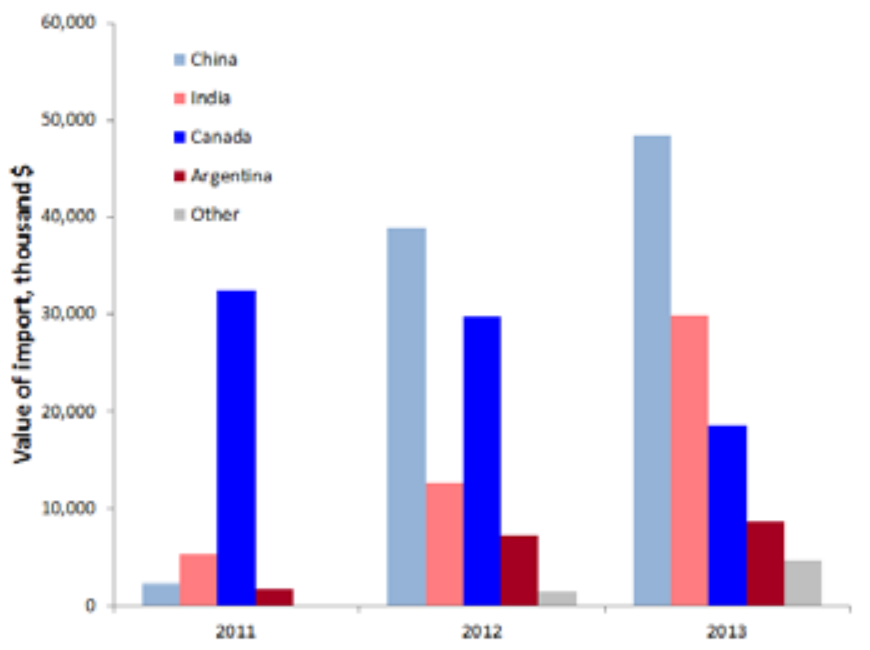

Figure 8. Value of certified National Organic Program soybeans imported into the United States, 2011 through 2013. Source: United States Department of Agriculture Foreign Agricultural Service (2014a). See online version for figure in color.

animal production costs, the cost of animal products from animals fed non-GE feed would be more expensive.

\section{Impact of Genetically Engineered Feedstuffs on the Sustainability of Livestock Production}

Feedstuffs are a major contributor to life cycle assessments in the production of meat, milk, and eggs on a national and global scale. By 2020, developing countries will consume 107 million t more meat and 177 million $\mathrm{t}$ more milk than the annual average of the years 1996 through 1998. The projected increase in livestock production will require annual feed consumption of cereals to rise by nearly 300 million t by 2020 (Delgado, 2003). Despite the fact that the first generation of GE crops with so-called "input" traits (those that potentially alter inputs needed in production) were not designed to increase crops yields per se, GE technology has added an estimated 122 and 230 million $t$ to the global production of soybeans and corn, respectively, since the introduction of GE varieties in the mid 1990s (Brookes and Barfoot, 2014a).

In 2013, approximately 175.2 million ha of GE crops were cultivated worldwide (James, 2013) by 18 million farmers. Over $90 \%$ (>16.5 million) were small-scale, resource-poor farmers in developing countries. This planting was greater than a 100-fold increase from the 1.7 million ha that were planted in 1996, making GE the fastest-adopted crop technology in recent history. India cultivated 11.0 million ha of $\mathrm{Bt}$ cotton with an adoption rate of 95\%. In China, 7.5 million farmers cultivating an average of approximately 0.5 ha collectively grew 4.2 million ha of Bt cotton, an adoption rate of $90 \%$. Farmers have planted these GE varieties to enable the adoption of improved agronomic practices (e.g., reduced insecticide applications) providing environmental, economic, 
and food security benefits in various countries (Ali and Abdulai, 2010; Burachik, 2010; Fernandez-Cornejo et al., 2014; Huang et al., 2010; Kathage and Qaim, 2012; Qaim and Kouser, 2013).

During the period 1996 through 2012, it has been estimated that the cumulative economic benefits from cost savings and added income derived from planting GE crops was $\$ 58.15$ billion in developing countries and $\$ 58.45$ billion in industrial countries (Brookes and Barfoot, 2014a). The adoption of the technology also reduced pesticide spraying by 499 million $\mathrm{kg}(-8.7 \%)$, and has decreased the environmental impact of these crops by $18.1 \%$ (as measured by the indicator the Environmental Impact Quotient [a method that measures the environmental impact of pesticides]; Kovach et al., 1992) as a result of the use of less-toxic herbicides and reduced insecticide use (Brookes and Barfoot, 2014b). As a result of fuel savings associated with making fewer spray runs, the adoption of production systems with reduced tillage, and additional soil carbon sequestration, GE crops have also resulted in a significant reduction in the release of greenhouse gas emissions, which, in 2012 alone, was equivalent to removing 11.88 million cars from the roads (Brookes and Barfoot, 2014b).

Although some weed resistance has developed as a result of poor pest management practices and overreliance on a single herbicide (i.e., glyphosate), which may impact future benefits, the adoption of GE technology by the major livestock feed producing countries over the past $16 \mathrm{yr}$ has had a positive sustainability outcome both in terms of increased global yield as a result of improved pest control and reduced overall environmental impacts per kilogram of animal feed produced.

\section{The Future}

There are numerous GE crops enhanced for animal nutrition in the research and development pipeline, with almost 100 events under research in many countries of the world (Tillie et al., 2013). This reflects both the importance of feed markets for GE crops and the potential nutritional improvements that can be brought to the quality of feedstuffs using this technology. There are 2 ways in which plant breeding might increase the efficiency of livestock production; the first is by raising the crop yield per hectare (e.g., improved drought tolerance or $\mathrm{N}$ use efficiency) and the second is by improving the rate of conversion of vegetable calories into animal calories (e.g., altered output traits or crop composition). Genetic engineering offers new possibilities for approaching both of these objectives, including improving the nutritional value of feed (e.g., AA content; Huang et al., 2006), lowering $\mathrm{N}$ and P pollution through altered crop composition (e.g., low phytate; Chen et al., 2008), and reducing manure excretion through a higher NE value (e.g., reduced lignin; Jung et al., 2012). Several of these crops are far advanced in the regulatory pipeline (Table 8; Tillie et al., 2013)

These so-called "second generation" crops modified for output traits will pose some regulatory and commercialization challenges. The first is that they will not, by definition, be substantially equivalent to isogenic non-GE varieties. Protocols have been developed to address the safety testing of these crops (International Life Sciences Institute, 2007). However, given the different regulatory approaches that are in place for crops that are compositionally equivalent, it is unclear how regulatory requirements may vary between countries in terms of the number and length of target animal feeding studies for these crops with altered output traits. Additionally, if the benefits derived from growing these crops accrue to the livestock producer or feeder and not directly to the farmer growing the crop, there will need to be some form of supply chain segregation in place to ensure a price premium is obtained for the value-added output trait.

An additional concern is the increasing problem of asynchronous regulatory approval, or regulatory asynchronicity. Currently, 33 countries have regulatory systems that handle approval for the cultivation or importation of new GE crops (International Service for the Acquisition of Agri-Biotech Applications, 2014). There are considerable discrepancies in the amount of time required to review and approve new GE crops in different countries. This leads to a situation where GE crops may be cultivated and marketed in some countries and remain unapproved in others. As discussed previously, this has resulted in trade disruptions, especially when countries use a "zero-tolerance" policy for unapproved events, meaning that even minute traces of unapproved GE crops are illegal and must be withdrawn from the market. Under a zero-tolerance policy, trade of relevant commodities between asynchronous countries will likely cease as importing and exporting firms will act to avoid the risk associated with a positive test (Kalaitzandonakes et al., 2014). Countries with zero-tolerance policies will be perceived as risky export markets, and importers will pay higher prices and insurance premiums to offset risks taken by the supplier.

Currently, the most accepted techniques for the detection of rDNA and protein products are PCR and ELISA, respectively. Various analytical methods have been developed and are routinely used for the monitoring of GE origin in raw materials and processed foods and have been reviewed elsewhere (Alexander et al., 2007; Marmiroli et al., 2008). Although efforts have been taken to harmonize analytical methodology for the detection of GE products at national, regional, and international levels, no international standards have yet been established (Holst-Jensen et al., 2006). Sampling, testing, and cer- 
Table 8. Summary of genetically engineered crops modified for output traits in the latest stages of the pipeline. Modified from Tillie et al. (2013).

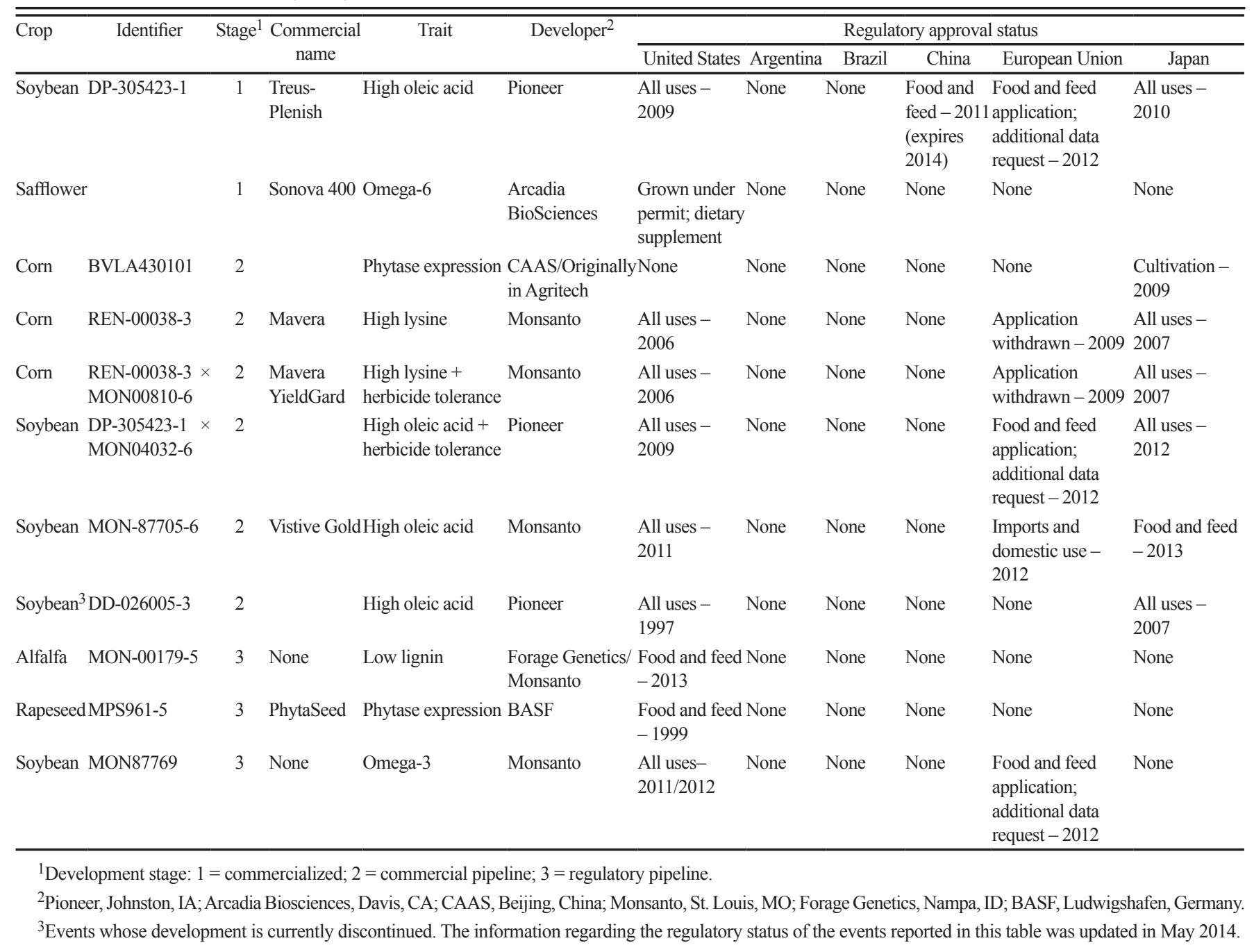

tification depend on statistical processes, however, and hence all are subject to some error, which increases at very low tolerances (Lamb and Booker, 2011).

Kalaitzandonakes et al. (2014) succinctly summarizes some emerging trends in terms of likely increased regulatory asynchronicity in the future. These include 1) the expanding pipeline of novel GE crop events, including second generation crops modified for output traits; 2) the expanding range of GE crop species being grown and traded; 3) the expanding global hectarage of GE crops and the growing number of countries that raise them; and 4) the nascent and inexperienced regulatory expertise in many countries that will be called on to manage a large number of regulatory submissions for new GE crops in the future. Given the scope of trade of livestock feedstuffs and the increasing importance of GE crops in this supply, trade disruptions appear imminent, especially in countries that have slow approval processes for GE imports and yet are heavily dependent on commodity imports from ex- porting countries that are cultivating and developing a large number of GE crop varieties.

The emergence of precise gene-editing technologies (e.g., zinc finger nucleases [ZFN], meganucleases, transcription activator-like effector nucleases [TALEN], oligonucleotide-directed mutagenesis, and clustered regulatory interspaced short palindromic repeat [CRISPR]/ Cas-based RNA-guided DNA endonucleases) that enable targeted editing of specific nucleotides in the endogenous genome (Kim and Kim, 2014) will further complicate this situation. Gene editing could be considered a form of directed mutagenesis and it is unclear whether gene-editing technologies for crops and animals will be encompassed by the GE regulatory system. This is especially uncertain where gene editing results in the substitution of 1 naturally occurring allelic form of a gene for another of the same gene or induces a mutation in an existing gene through a single base pair change analogous to the spontaneous mutation process (Wells, 2013). Whether these types of modifications should be subject to regulation is a topic of dis- 
cussion among the global regulatory community (Bruce et al., 2013; Hartung and Schiemann, 2014; Lusser and Davies, 2013). Given that the regulatory process takes years and costs millions of dollars (Prado et al., 2014), the governance of emerging gene-editing technologies will have a great influence on the future development of crops carrying these genetic modifications and will significantly impact the ability of the public sector and small companies to bring gene-edited products to market.

Of particular practical importance is that there will be no way to differentiate a gene-edited DNA alteration from a naturally occurring mutation and hence no way to trace and track "genetically modified" gene-edited crops or differentiate them from genetic modifications resulting from spontaneous mutations. Many of the existing PCR-based tests for GE crops are designed using primers that amplify unique DNA sequences that are common to a variety of transgenic crops (e.g., exogenous promoter sequence or gene coding sequence). As new GE crops with multiple novel regulatory and coding region sequences are developed, it will be increasingly difficult to use PCRbased assays to detect all possible events. Furthermore, PCR-based screening methodology may be unable to detect the genetic modifications that are under development through precise breeding techniques (Lusser et al., 2012). Likewise, some gene-editing techniques generate genetic changes that cannot be distinguished from conventionally bred crops or from crops produced by natural genetic variation or unregulated radiation mutagenesis (Broeders et al., 2012). Process-based regulatory frameworks that rely on PCR-based detection of specific transgenic constructs will be unable keep pace with technological developments when the products of these advanced breeding techniques are indistinguishable from those produced using conventional breeding techniques.

These developments may lead to a revaluation of the current rDNA process-based regulatory trigger for GE organisms to a more scientifically defensible product-based approach centered on the novelty and any unique risks associated with the phenotype of the product rather than the process used to accomplish the genetic modification (Bradford et al., 2005; McHughen, 2007). The need for international coordination and synchronization of regulatory frameworks for GE products is becoming increasingly urgent as both research and development of GE crops and animals are proceeding at an accelerated rate in an ever increasing number of countries in the world. In the absence of international harmonization, costly trade disruptions are likely to become increasingly widespread in the future to the detriment of global food security.

\section{Conclusions}

Commercial livestock populations are the largest consumers of GE crops, and globally, billions of animals have been eating GE feed for almost 2 decades. An extensive search of peer-reviewed literature and field observations of animals fed diets containing GE crop products have revealed no unexpected perturbations or disturbing trends in animal performance or health indicators. Likewise, it is not possible to distinguish any differences in the nutritional profile of animal products following consumption of GE feed. Animal agriculture is currently highly dependent on GE feed sources, and global trade of livestock feed is largely supplied by countries that have approved the cultivation of GE crops. Supplying non-GE-fed animal products is likely to become increasingly expensive given the expanding global planting of GE crops and the growing number of countries that raise them. The market for animals that have not consumed GE feed is currently a niche market in the United States, although such products are available to interested consumers via voluntary processbased marketing programs. The cost of these products is higher than conventionally produced products due to both the higher cost of non-GE feed and the costs associated with certifying the absence of GE crops in the production process and product segregation. There is currently a pipeline of so-called "second generation" GE crops with improved output traits for livestock production. Their approval will further complicate the sourcing of non-GE feedstuffs. Additionally, recent developments in techniques to induce precise genetic changes in targeted genes offer both tremendous opportunities and a challenge for global regulatory oversight. Given these developments, there is an urgent need for international harmonization of both regulatory frameworks for GE crops and governance of advanced breeding techniques to prevent widespread disruptions in international trade of livestock feedstuffs in the future.

\section{LITERATURE CITED}

Agodi, A., M. Barchitta, A. Grillo, and S. Sciacca. 2006. Detection of genetically modified DNA sequences in milk from The Italian market. Int. J. Hyg. Environ. Health 209:81-88.

Alexander, T. W., T. Reuter, K. Aulrich, R. Sharma, E. K. Okine, W. T. Dixon, and T. A. McAllister. 2007. A review of the detection and fate of novel plant molecules derived from biotechnology in livestock production. Anim. Feed Sci. Technol. 133:31-62.

Ali, A., and A. Abdulai. 2010. The adoption of genetically modified cotton and poverty reduction in Pakistan. J. Agric. Econ. 61:175-192.

Areal, F. J., L. Riesgo, and E. Rodrigues-Cerezo. 2013. Economic and agronomic impact of commercialized GM crops: A metaanalysis. J. Agric. Sci. 151:7-33. 
Arjó, G., M. Portero, C. Piñol, J. Viñas, X. Matias-Guiu, T. Capell, A. Bartholomaeus, W. Parrott, and P. Christou. 2013. Plurality of opinion, scientific discourse and pseudoscience: An in depth analysis of the Séralini et al. study claiming that Roundup ${ }^{\mathrm{TM}}$ Ready corn or the herbicide Roundup ${ }^{\mathrm{TM}}$ cause cancer in rats. Transgenic Res. 22:255-267.

Aumaitre, A., K. Aulrich, A. Chesson, G. Flachowsky, and G. Piva. 2002. New feeds from genetically modified plants: Substantial equivalence, nutritional equivalence, digestibility, and safety for animals and the food chain. Livest. Prod. Sci. 74:223-238.

The Australian and New Zealand Food Standards Agency. 2012. Response to Séralini paper on the long term toxicity of a Roundup herbicide and a Roundup-tolerant genetically modified maize. www.foodstandards.gov.au/consumer/gmfood/seralini/Pages/default.aspx (Accessed May 28, 2014).

The Australian and New Zealand Food Standards Agency. 2013. Detailed comment on Carman et al. (2013): Study design and conduct. www.foodstandards.gov.au/consumer/gmfood/Pages/ Detailed-commentary-.aspx (Accessed May 28, 2014).

Bartholomaeus, A., W. Parrott, G. Bondy, and K. Walker. 2013. The use of whole food animal studies in the safety assessment of genetically modified crops: Limitations and recommendations. Crit. Rev. Toxicol. 43:1-24.

Beever, D. E., and C. F. Kemp. 2000. Safety issues associated with the DNA in animal feed derived from genetically modified crops. A review of scientific and regulatory procedures. Nutr. Abstr. Rev., Ser. B: Livest. Feeds Feed. 70:175-182.

Bertheau, Y., J. C. Helbling, M. N. Fortabat, S. Makhzami, I. Sotinel, C. Audéon, A. C. Nignol, A. Kobilinsky, L. Petit, P. Fach, P. Brunschwig, K. Duhem, and P. Martin. 2009. Persistence of plant DNA sequences in the blood of dairy cows fed with genetically modified (Bt176) and conventional corn silage. J. Agric. Food Chem. 57:509-516.

Boleman, S. L., S. J. Boleman, W. W. Morgan, D. S. Hale, D. B. Griffin, J. W. Savell, R. P. Ames, M. T. Smith, J. D. Tatum, T. G. Field, G. C. Smith, B. A. Gardner, J. B. Morgan, S. L. Northcutt, H. G. Dolezal, D. R. Gill, and F. K. Ray. 1998. National Beef Quality Audit-1995: Survey of producer-related defects and carcass quality and quantity attributes. J. Anim. Sci. 76:96-103.

Bradford, K. J., A. Van Deynze, N. Gutterson, W. Parrott, and S. H. Strauss. 2005. Regulating transgenic crops sensibly: Lessons from plant breeding, biotechnology and genomics. Nat. Biotechnol. 23:439-444.

Brake, D. G., and D. P. Evenson. 2004. A generational study of glyphosate-tolerant soybeans on mouse fetal, postnatal, pubertal and adult testicular development. Food Chem. Toxicol. 42:29-36.

Broeders, S. R. M., S. C. J. De Keersmaecker, and N. H. C. Roosens. 2012. How to deal with the upcoming challenges in GMO detection in food and feed. J. Biomed. Biotechnol. 2012:1-11.

Brookes, G., and P. Barfoot. 2014a. The global income and production effects of genetically modified (GM) crops 1996-2012. GM Crops Food 5:65-75.

Brookes, G., and P. Barfoot. 2014b. Key global environmental impacts of genetically modified (GM) crop use 1996-2012. GM Crops Food 5:149-160.

Brookes, G., and P. Barfoot. 2014c. GM crops: Global socio-economic and environmental impacts 1996-2012. PG Economics Ltd, UK. www.pgeconomics.co.uk/pdf/2014globalimpactstudy finalreport.pdf (Accessed May 28, 2014).

Bruce, A., D. Castle, C. Gibbs, J. Tait, and C. B. Whitelaw. 2013. Novel GM animal technologies and their governance. Transgenic Res. 22:681-695.
Bruinsma, J. 2009. The Resource Outlook to 2010: By How Much Do Land, Water and Crop Yields Need to Increase by 2050? Expert Meeting on How to Feed the World in 2050, 24-26 June, Rome, Italy.

Burachik, M. 2010. Experience from use of GMOs in Argentinian agriculture, economy and environment. N. Biotechnol. 27:588-592.

Buzoianu, S. G., M. C. Walsh, M. C. Rea, J. P. Cassidy, R. P. Ross, G. E. Gardiner, and P. G. Lawlor. 2012a. Effect of feeding genetically modified Bt MON810 maize to approximately 40-day-old pigs for 110 days on growth and health indicators. Animal 6:1609-1619.

Buzoianu, S. G., M. C. Walsh, M. C. Rea, J. P. Cassidy, T. P. Ryan, R. P. Ross, G. E. Gardiner, and P. G. Lawlor. 2013a. Transgenerational effects of feeding genetically modified maize to nulliparous sows and offspring on offspring growth and health. J. Anim. Sci. 91:318-330.

Buzoianu, S. G., M. C. Walsh, M. C. Rea, O. O'Donovan, E. Gelencsér, G. Ujhelyi, E. Szabó, A. Nagy, R. P. Ross, G. E. Gardiner, and P. G. Lawlor. 2012b. Effects of feeding Bt maize to sows during gestation and lactation on maternal and offspring immunity and fate of transgenic material. PLoS ONE 7:E47851.

Buzoianu, S. G., M. C. Walsh, M. C. Rea, O. O'Sullivan, P. D. Cotter, R. P. Ross, G. E. Gardiner, and P. G. Lawlor. 2012c. Highthroughput sequence-based analysis of the intestinal microbiota of weanling pigs fed genetically modified MON810 maize expressing Bacillus thuringiensis Cry1 Ab (Bt maize) for 31 days. Appl. Environ. Microbiol. 78:4217-4224.

Buzoianu, S. G., M. C. Walsh, M. C. Rea, O. O’Sullivan, F. Crispie, P. D. Cotter, R. P. Ross, G. E. Gardiner, and P. G. Lawlor. 2012d. The effect of feeding Bt MON810 maize to pigs for 110 days on intestinal microbiota. PLoS ONE 7:E33668.

Buzoianu, S. G., M. C. Walsh, M. C. Rea, L. Quigley, O. O'Sullivan, P. D. Cotter, R. P. Ross, G. E. Gardiner, and P. G. Lawlor. 2013b. Sequence-based analysis of the intestinal Microbiota of sows and their offspring fed genetically modified maize expressing a truncated form of Bacillus thuringiensis Cry1 Ab protein (Bt Maize). Appl. Environ. Microbiol. 79:7735-7744.

Carman, J. A., H. R. Vlieger, L. J. Ver Steeg, V. E. Sneller, G. W. Robinson, C. A. Clinch-Jones, J. I. Haynes, and J. W. Edwards. 2013. A long-term toxicology study on pigs fed a combined genetically modified (GM) soy and GM maize diet. J. Org. Syst. 8:38-54.

Chen, R., G. Xue, P. Chen, B. Yao, W. Yang, Q. Ma, Y. Fan, Z. Zhao, M. C. Tarczynski, and J. Shi. 2008. Transgenic maize plants expressing a fungal phytase gene. Transgenic Res. 17:633-643.

Cheng, K. C., J. Beaulieu, E. Iquira, F. J. Belzile, M. G. Fortin, and M. V. Stromvik. 2008. Effect of transgenes on global gene expression in soybean is within the natural range of variation of conventional cultivars. J. Agric. Food Chem. 56:3057-3067.

Council for Agricultural Science and Technology (CAST). 2006. Safety of meat, milk, and eggs from animals fed crops derived from modern biotechnology. Issue paper no. 34. CAST, Ames, IA.

Council for Agricultural Science and Technology (CAST). 2014. The potential impacts of mandatory labeling for genetically engineered food in the United States. Issue Paper 54. CAST, Ames, IA.

de Vendomois, J. S., F. Roullier, D. Cellier, and G. E. Séralini. 2009. A comparison of the effects of three GM corn varieties on mammalian health. Int. J. Biol. Sci. 5:706-726.

Deb, R., B. Sajjanar, K. Devi, K. Reddy, R. Prasad, S. Kumar, and A. Sharma. 2013. Feeding animals with GM crops: Boon or bane? Indian J. Biotechnol. 12:311-322.

DeFrancesco, L. 2013. How safe does transgenic food need to be? Nat. Biotechnol. 31:794-802.

Delgado, C. L. 2003. Rising consumption of meat and milk in developing countries has created a new food revolution. J. Nutr. 133:3907S-3910S. 
Dona, A., and I. S. Arvanitoyannis. 2009. Health risks of genetically modified foods. Crit. Rev. Food Sci. Nutr. 49:164-175.

Einspanier, R. 2013. The fate of transgenic DNA and newly expressed proteins. In: G. Flachowsky, editor, Animal nutrition with transgenic plants. CABI Biotechnology Series. CABI, Oxfordshire, UK. p. 112-127.

Einspanier, R., A. Klotz, J. Kraft, K. Aulrich, R. Poser, F. Schwägele, G. Jahreis, and G. Flachowsky. 2001. The fate of forage plant DNA in farm animals: A collaborative case-study investigating cattle and chicken fed recombinant plant material. Eur. Food Res. Technol. 212:129-134.

Ermakova, I. V. 2005. Influence of genetically modified-SOYA on the birth-weight and survival of rat pups: Preliminary study. www.mindfully.org/GE/2005/Modified-Soya-Rats10oct05.htm (Accessed May 28, 2014).

European Feed Manufacturers' Federation. 2013. XXVI FEFAC congress 2013. The feed chain in action. www.fefac.eu/files/46541. pdf (Accessed May 28, 2014).

European Food Safety Authority. 2008. Safety and nutritional assessment of GM plants and derived food and feed: The role of animal feeding trials. Food Chem. Toxicol. 46(Suppl. 1):S2-S70.

European Food Safety Authority. 2011. Opinion of the scientific committee/scientific panel. Statistical significance and biological relevance. EFSA J. 9:2372-2389.

European Food Safety Authority. 2012. Final review of the Séralini et al. (2012) publication on a 2-year rodent feeding study with glyphosate formulations and GM maize NK603 as published online on 19 September 2012 in Food and Chemical Toxicology. Statement of EFSA. EFSA J. 10:2986-2996.

Ewen, S. W., and A. Pusztai. 1999. Effect of diets containing genetically modified potatoes expressing Galanthus nivalis lectin on rat small intestine. Lancet 354:1353-1354.

Faust, M. 2002. New feeds from genetically modified plants: The US approach to safety for animals and the food chain. Livest. Prod. Sci. 74:239-254.

Federation of Animal Science Societies. 2014. ReferencesFeeding Transgenic Crops to Livestock. www.fass.org/page. asp?pageID=52 (Accessed May 28, 2014).

Fernandez-Cornejo, J., S. Wechsler, M. Livingston, and L. Mitchell. 2014. Genetically engineered crops in the United States, ERR162. www.ers.usda.gov/publications/err-economic-researchreport/err162.aspx\#.U4TWAvldVu0 (Accessed May 28, 2014).

Flachowsky, G. 2013. Feeding studies with first generation GM plants (input traits) with food-producing animals. In: G. Flachowsky, editor, Animal nutrition with transgenic plants. CABI Biotechnology Series. CABI, Oxfordshire, UK. p. 72-93.

Flachowsky, G., H. Schafft, and U. Meyer. 2012. Animal feeding studies for nutritional and safety assessments of feeds from genetically modified plants: A review. J. Verbraucherschutz Lebensmittelsicherh. 7:179-194.

Food and Agriculture Organization of the United Nations. 2012. FAO statistical yearbook 2012. www.fao.org/docrep/015/i2490e/ i2490e00.htm (Accessed May 28, 2014).

Garcia-Villalba, R., C. Leon, G. Dinelli, A. Segura-Carretero, A. Fernandez-Gutierrez, V. Garcia-Canas, and A. Cifuentes. 2008. Comparative metabolomic study of transgenic versus conventional soybean using capillary electrophoresis-time-of-flight mass spectrometry. J. Chromatogr. A 1195:164-173.

Green, J. M. 2012. The benefits of herbicide-resistant crops. Pest Manag. Sci. 68:1323-1331.
Grow, S., and C. Greene. 2009. The structural evolution of organic farms in the USA: The international market effect. In: M. E. A. Canavari, editor, International marketing and trade of quality food products. Wageningen Academic Publishers, The Netherlands. p. 239-250.

Gruère, G. P, and S. R. Rao. 2007. A review of international labeling policies of genetically modified food to evaluate India's proposed rule. AgBioForum, 10: 51-64.

Guertler, P., C. Brandl, H. D. Meyer, and A. Tichopad. 2012. Feeding genetically modified maize (MON810) to dairy cows: Comparison of gene expression pattern of markers for apoptosis, inflammation and cell cycle. J. Verbraucherschutz Lebensmittelsicherh. 7:195-202.

Guertler, P., V. Paul, K. Steinke, S. Wiedemann, W. Preißinger, C. Albrecht, H. Spiekers, F. J. Schwarz, and H. H. D. Meyer. 2010. Long-term feeding of genetically modified corn (MON810)Fate of cry1Ab DNA and recombinant protein during the metabolism of the dairy cow. Livest. Sci. 131:250-259.

Hafla, A., J. MacAdam, and K. Soder. 2013. Sustainability of US organic beef and dairy production systems: Soil, plant and cattle interactions. Sustainability 5:3009-3034.

Hartung, F., and J. Schiemann. 2014. Precise plant breeding using new genome editing techniques: Opportunities, safety and regulation in the EU. Plant J. 78:742-752.

Havenstein, G. B., P. R. Ferket, and M. A. Qureshi. 2003. Growth, livability and feed conversion of 1957 versus 2001 broilers when fed representative 1957 and 2001 broiler diets. Poult. Sci. 82:1500-1508.

Herman, R. A., and W. D. Price. 2013. Unintended compositional changes in genetically modified (GM) crops: 20 years of research. J. Agric. Food Chem. 61:11695-11701.

Hollingworth, R. M., L. F. Bjeldanes, M. Bolger, I. Kimber, B. J. Meade, S. L. Taylor, K. B. Wallace, and Society of Toxicology ad hoc Working Group. 2003. The safety of genetically modified foods produced through biotechnology. Toxicol. Sci. 71:2-8.

Holst-Jensen, A., M. De Loose, and G. Van den Eede. 2006. Coherence between legal requirements and approaches for detection of genetically modified organisms (GMOs) and their derived products. J. Agric. Food Chem. 54:2799-2809.

Huang, J., J. Mi, H. Lin, Z. Wang, R. Chen, R. Hu, S. Rozelle, and C. Pray. 2010. A decade of Bt cotton in Chinese fields: Assessing the direct effects and indirect externalities of Bt cotton adoption in China. Sci. China Life Sci. 53:981-991.

Huang, S., A. Frizzi, C. Florida, D. Kruger, and M. Luethy. 2006. High lysine and high tryptophan transgenic maize resulting from the reduction of both 19- and 22-kD $\alpha$-zeins. Plant Mol. Biol. 61:525-535.

International Life Sciences Institute. 2003. Best practices for the conduct of animal studies to evaluate crops genetically modified for input traits. International Life Sciences Institute, Washington, DC.

International Life Sciences Institute. 2007. Best practices for the conduct of animal studies to evaluate crops genetically modified for output traits. International Life Sciences Institute, Washington, DC.

International Service for the Acquisition of Agri-Biotech Applications. 2014. GM approval database. www.isaaa.org/gmapprovaldatabase/default.asp (Accessed May 28, 2014).

James, C. 2013. Global status of commercialized biotech/GM crops: 2013. The International Service for the Acquisition of Agribiotech Applications (ISAAA) brief no. 46. ISAAA, Ithaca, NY.

Jonas, D. A., I. Elmadfa, K.-H. Engel, K. J. Heller, G. Kozianowski, A. Konig, D. Muller, J. F. Narbonne, W. Wackernagel, and J. Kleiner. 2001. Safety considerations of DNA in food. Ann. Nutr. Metab. 45:235-254.

Jung, H.-J. G., D. A. Samac, and G. Sarath. 2012. Modifying crops to increase cell wall digestibility. Plant Sci. 185-186:65-77. 
Kalaitzandonakes, N., J. Kaufman, and D. Miller. 2014. Potential economic impacts of zero thresholds for unapproved GMOs: The EU case. Food Policy 45:146-157.

Kathage, J., and M. Qaim. 2012. Economic impacts and impact dynamics of Bt (Bacillus thuringiensis) cotton in India. Proc. Natl. Acad. Sci. U. S. A. 109:11652-11656.

Kilic, A., and M. T. Akay. 2008. A three generation study with genetically modified Bt corn in rats: Biochemical and histopathological investigation. Food Chem. Toxicol. 46:1164-1170.

Kim, H., and J.-S. Kim. 2014. A guide to genome engineering with programmable nucleases. Nat. Rev. Genet. 15:321-334.

Kovach, J., C. Petzoldt, J. Degni, and J. Tette. 1992. A Method to Measure the Environmental Impact of Pesticides. New York Food and Life Sciences Bulletin Number 139.

Kuiper, H. A., E. J. Kok, and H. V. Davies. 2013. New EU legislation for risk assessment of GM food: No scientific justification for mandatory animal feeding trials. Plant Biotechnol. J. 11:781-784.

Lamb, E. G., and H. M. Booker. 2011. Quantification of low-level genetically modified (GM) seed presence in large seed lots: A case study of GM seed in Canadian flax breeder seed lots. Seed Sci. Res. 21:315-321.

Lusser, M., and H. V. Davies. 2013. Comparative regulatory approaches for groups of new plant breeding techniques. $\mathrm{N}$. Biotechnol. 30:437-446.

Lusser, M., C. Parisi, D. Plan, and E. Rodriguez-Cerezo. 2012. Deployment of new biotechnologies in plant breeding. Nat. Biotechnol. 30:231-239.

Malatesta, M., M. Biggiogera, E. Manuali, M. B. Rocchi, B. Baldelli, and G. Gazzanelli. 2003. Fine structural analyses of pancreatic acinar cell nuclei from mice fed on genetically modified soybean. Eur. J. Histochem. 47:385-388.

Malatesta, M., F. Boraldi, G. Annovi, B. Baldelli, S. Battistelli, M. Biggiogera, and D. Quaglino. 2008. A long-term study on female mice fed on a genetically modified soybean: Effects on liver ageing. Histochem. Cell Biol. 130:967-977.

Malatesta, M., C. Caporaloni, S. Gavaudan, M. B. Rocchi, S. Serafini, C. Tiberi, and G. Gazzanelli. 2002a. Ultrastructural morphometrical and immunocytochemical analyses of hepatocyte nuclei from mice fed on genetically modified soybean. Cell Struct. Funct. 27:173-180.

Malatesta, M., C. Caporaloni, L. Rossi, S. Battistelli, M. Rocchi, F. Tonucci, and G. Gazzanelli. 2002b. Ultrastructural analysis of pancreatic acinar cells from mice fed on genetically modified soybean. J. Anat. 201:409-415.

Malatesta, M., C. Tiberi, B. Baldelli, S. Battistelli, E. Manuali, and M. Biggiogera. 2005. Reversibility of hepatocyte nuclear modifications in mice fed on genetically modified soybean. Eur. J. Histochem. 49:237-242.

Marmiroli, N., E. Maestri, M. Gullì, A. Malcevschi, C. Peano, R. Bordoni, and G. Bellis. 2008. Methods for detection of GMOs in food and feed. Anal. Bioanal. Chem. 392:369-384.

Marshall, A. 2007. GM soybeans and health safety - A controversy reexamined. Nat. Biotechnol. 25:981-987.

Mathews, K. H., and R. J. Johnson. 2013. Alternative beef production systems: Issues and implications. United States Department of Agriculture, Economic Research Service. LDPM-218-01. www.ers.usda.gov/media/1071057/1dpm-218-01.pdf (Accessed May 28, 2014).

McHughen, A. 2007. Fatal flaws in agbiotech regulatory policies. Nat. Biotechnol. 25:725-727.

National Chicken Council. 2011. U.S. broiler performance. www. nationalchickencouncil.org/about-the-industry/statistics/u-sbroiler-performance/ (Accessed May 28, 2014).
National Grain and Feed Association. 2014. NGFA estimates up to \$2.9 billion loss to U.S. corn, soy in aftermath of trade disruption with china over detection of unapproved Syngenta Agrisure Viptera ${ }^{\mathrm{TM}}$ MIR 162 corn. www.ngfa.org/2014/04/21/ngfa-estimates-up-to2-9-billion-loss-to-u-s-corn-soy-in-aftermath-of-trade-disruption-with-china-over-detection-of-unapproved-syngenta-agrisure-viptera-mir-162-corn-2/ (Accessed May 28, 2014).

NRC. 2010. Impact of genetically engineered crops on farm sustainability in the United States. The National Academies Press, Washington, D.C.

Organisation for Economic Co-operation and Development (OECD). 1998. (Part 408), Health effects: Repeated dose 90-day oral toxicity study in rodents, guideline for the testing of chemicals. OECD, Paris.

Petersson, E. V., U. Arif, V. Schulzova, V. Krtková, J. Haj'lová, J. Meijer, H. C. Andersson, L. Jonsson, and F. Sitbon. 2013. Glycoalkaloid and calystegine levels in table potato cultivars subjected to wounding, light, and heat treatments. J. Agric. Food Chem. 61:5893-5902.

Popp, J., K. Pető, R. Magda, and Z. Lakner. 2013. Economic impact of GM hysteria on EU feed market. Am. J. Plant Sci. 4:1547-1553.

Prado, J. R., G. Segers, T. Voelker, D. Carson, R. Dobert, J. Phillips, K. Cook, C. Cornejo, J. Monken, L. Grapes, T. Reynolds, and S. Martino-Catt. 2014. Genetically engineered crops: From idea to product. Annu. Rev. Plant Biol. 65:769-790.

Qaim, M., and S. Kouser. 2013. Genetically modified crops and food security. PLoS ONE 8(6):E64879.

Rhee, G. S., D. H. Cho, Y. H. Won, J. H. Seok, S. S. Kim, S. J. Kwack, R. D. Lee, S. Y. Chae, J. W. Kim, B. M. Lee, K. L. Park, and K. S. Choi. 2005. Multigeneration reproductive and developmental toxicity study of bar gene inserted into genetically modified potato on rats. J. Toxicol. Environ. Health A 68:2263-2276.

Rickard, C. 2009. Letter to the editor. Crit. Rev. Food Sci. Nutr. 50:85-91.

Ricroch, A. E. 2013. Assessment of GE food safety using '-omics' techniques and long-term animal feeding studies. N. Biotechnol. 30:349-354.

Ricroch, A. E., A. Berheim, C. Snell, G. Pascal, A. Paris, and M. Kuntz. 2013. Long-term and multi-generational animal feeding studies. In: G. Flachowsky, editor, Animal nutrition with transgenic plants. CABI Biotechnology Series. CABI, Oxfordshire, UK. p. 112-127.

Schorsch, F. 2013. Serious inadequacies regarding the pathology data presented in the paper by Séralini et al. (2012). Food Chem. Toxicol. 53:465-466.

Séralini, G.-E., D. Cellier, and J. S. De Vendomois. 2007. New analysis of a rat feeding study with a genetically modified maize reveals signs of hepatorenal toxicity. Arch. Environ. Contam. Toxicol. 52:596-602.

Séralini, G.-E., E. Clair, R. Mesnage, S. Gress, N. Defarge, M. Malatesta, D. Hennequin, and J. S. de Vendômois. 2012. Long term toxicity of a Roundup herbicide and a Roundup-tolerant genetically modified maize. Food Chem. Toxicol. 50:42214231 RETRACTED.

Séralini, G.-E., E. Clair, R. Mesnage, S. Gress, N. Defarge, M. Malatesta, D. Hennequin, and J. S. de Vendômois. 2014. Republished study: Long-term toxicity of a Roundup herbicide and a Roundup-tolerant genetically modified maize. Environ. Sci. Eur. 26:1-17.

Snell, C., A. Bernheim, J. B. Berge, M. Kuntz, G. Pascal, A. Paris, and A. E. Ricroch. 2012. Assessment of the health impact of GM plant diets in long-term and multigenerational animal feeding trials: A literature review. Food Chem. Toxicol. 50:1134-1148. 
Steinke, K., P. Guertler, V. Paul, S. Wiedemann, T. Ettle, C. Albrecht, H. H. Meyer, H. Spiekers, and F. J. Schwarz. 2010. Effects of long-term feeding of genetically modified corn (event MON810) on the performance of lactating dairy cows. J. Anim. Physiol. Anim. Nutr. (Berl.) 94:E185-E193.

Tillie, P., K. Dillen, and E. Rodríguez-Cerezo. 2013. The pipeline of GM crops for improved animal feed: Challenges for commercial use. In: G. Flachowsky, editor, Animal nutrition with transgenic plants. CABI Biotechnology Series. CABI, Oxfordshire, UK. p. 166-187.

Tufarelli, V., and V. Laudadio. 2013. Genetically modified feeds in poultry diet: Safety, performance and product quality. Crit. Rev. Food Sci. Nutr. doi:10.1080/10408398.2012.667017

USDA Economic Research Service. 2008. Global agricultural supply and demand: Factors contributing to the recent increase in food commodity prices. www.growthenergy.org/images/reports/USDA Global_Agricultural_Supply_and_Demand.pdf (Accessed May 28, 2014).

USDA Economic Research Service. 2012a. Retail prices for organic and conventional eggs, monthly, 2004-07. www.ers.usda.gov/ dataFiles/Organic_Prices/Archive/retailorganicconventionalprices.xls (Accessed May 28, 2014).

USDA Economic Research Service. 2012b. Retail prices for organic and conventional milk, monthly, 2004-07. www.ers.usda.gov/ dataFiles/Organic_Prices/Archive/retailorganicconventionalprices.xls (Accessed May 28, 2014).

USDA Economics, Statistics, and Market Information System. 2013. http://usda.mannlib.cornell.edu/MannUsda/homepage.do (Accessed May 28, 2014).

USDA Economic Research Service. 2013. Table 3. Certified organic and total U.S. acreage, selected crops and livestock, 1995-2011. www.ers.usda.gov/data-products/organic-production.aspx\#. U_9blfldV8E (Accessed May 28, 2014).

USDA Food Safety and Inspection Service. 2003. Animal disposition reporting service (ADRS) fiscal year (FY) data. www.fsis.usda gov/OPHS/adrsdata/adrsfydx.htm (Accessed May 28, 2014.

USDA Foreign Agricultural Service. 2013a. Agricultural biotechnology annual. EU-27. GAIN report number: FR9142. www.usdafrance.fr/media/Agricultural\%20Biotechnology\%20Annual_ Paris_EU-27_7-12-2013.pdf(Accessed May 28, 2014).

USDA Foreign Agricultural Service. 2013b. Ukraine agricultural biotechnology annual report. GAIN report number: UP1326. http:/gain.fas.usda.gov/Recent\%20GAIN\%20 Publications/Agricultural\%20Biotechnology\%20Annual_ Kiev_Ukraine_8-9-2013.pdf(Accessed May 28, 2014).

USDA Foreign Agricultural Service. 2014a. Global Agricultural Trade System online (GATS) http://apps.fas.usda.gov/gats/ ExpressQuery1.aspx (Accessed May 28, 2014).

USDA Foreign Agricultural Service. 2014b. Grain: World markets and trade. http://apps.fas.usda.gov/psdonline/circulars/grain. pdf (Accessed May 28, 2014).
USDA Foreign Agricultural Service. 2014c. Poultry industry gives up GMO-free promise. GAIN report number: GM14008. http://gain.fas.usda.gov/Recent\%20GAIN\%20Publications/ German\%20poultry\%20industry\%20gives\%20up\%20promise $\% 20$ not $\% 20$ to $\% 20$ use $\% 20$ GMO $\% 20$ Soybeans $\% 20 \_B e r l i n$ Germany_2-19-2014.pdf (Accessed May 28, 2014).

USDA National Agricultural Statistics Service. 2012. 2011 Certified organic production survey. October 2012. United States Department of Agriculture, National Agricultural Statistics Service, Washington, DC. http://usda.mannlib.cornell.edu/usda/ current/OrganicProduction/OrganicProduction-10-04-2012.pdf (Accessed May 28, 2014).

USDA National Agricultural Statistics Service. 2013. Acreage. USDA. http://usda01.library.cornell.edu/usda/current/Acre/ Acre-06-28-2013.pdf (Accessed May 28, 2014).

Van Eenennaam, A. 2013. GMOs in animal agriculture: Time to consider both costs and benefits in regulatory evaluations. J. Anim. Sci. Biotechnol. 4:37.

Velmirov, A., C. Binter, and J. Zentek. 2008. Biological effects of transgenic maize NK603xMON810 fed in long term reproduction studies in mice. Bundesministerium fur Gesundheit, Familie und Jugend. www.biosicherheit.de/pdf/aktuell/zentek_ studie_2008.pdf (Accessed May 28, 2014).

Walsh, M. C., S. G. Buzoianu, G. E. Gardiner, M. C. Rea, E. Gelencser, A. Janosi, M. M. Epstein, R. P. Ross, and P. G. Lawlor. 2011. Fate of transgenic DNA from orally administered Bt MON810 maize and effects on immune response and growth in pigs. PLOS ONE 6:E27177.

Walsh, M. C., S. G. Buzoianu, G. E. Gardiner, M. C. Rea, O. O’Donovan, R. P. Ross, and P. G. Lawlor. 2013. Effects of feeding Bt MON810 maize to sows during first gestation and lactation on maternal and offspring health indicators. Br. J. Nutr. 109:873-881.

Walsh, M. C., S. G. Buzoianu, G. E. Gardiner, M. C. Rea, R. P. Ross, J. P. Cassidy, and P. G. Lawlor. 2012a. Effects of short-term feeding of Bt MON810 maize on growth performance, organ morphology and function in pigs. Br. J. Nutr. 107:364-371.

Walsh, M. C., S. G. Buzoianu, M. C. Rea, O. O’Donovan, E. Gelencser, G. Ujhelyi, R. P. Ross, G. E. Gardiner, and P. G. Lawlor. 2012b. Effects of feeding Bt MON810 maize to pigs for 110 days on peripheral immune response and digestive fate of the $c r y 1 A b$ gene and truncated Bt toxin. PLoS ONE 7:E36141.

Wells, K. D. 2013. Natural genotypes via genetic engineering. Proc. Natl. Acad. Sci. USA 110:16295-16296.

White, T. L., and D. A. Moore. 2009. Reasons for whole carcass condemnations of cattle in the United States and implications for producer education and veterinary intervention. J. Am. Vet. Med. Assoc. 235:937-941.

Whole Foods Market. 2013. Our Commitment to GMO Labeling: Where We Are on GMO Labeling Transparency. www.wholefoodsmarket. com/our-commitment-gmo-labeling (Accessed May 28, 2014). 